\title{
BROAD STROKES AND BRIGHT LINES: A RECONSIDERATION OF SHARI'A BASED RESERVATIONS
}

\section{TANYA MONFORTE*}

\section{INTRODUCTION}

\section{A. Opposition in International Law}

One of the most politically charged as well as legally technical problems occupying the field of international women's rights revolves around the reservations made to the Convention on the Elimination of All Forms of Discrimination against Women (CEDAW). ${ }^{1}$ An opposition among states became heated as several Muslim-majority states entered reservations to CEDAW invoking norms of Islamic Law, or Shari'a (sometimes referred to as either "Islamic reservations" or "Shari'a based reservations"). Several European states in turn lodged formal objections to these reservations. The row between European states and Muslim-majority states over the reservations has formed the basis for the technicalization of conflicting views on women's rights, in the depoliticizing sense of turning a political conflict into a seemingly technical legal one.

Reservations in international law are unilateral statements made by states to exclude

\footnotetext{
(C) 2017 Monforte. This is an open access article distributed under the terms of the Creative Commons Attribution License, which permits the user to copy, distribute, and transmit the work provided that the original author(s) and source are credited.

* O'Brien Fellow at the Center for Human Rights and Legal Pluralism at McGill University, Former Director of the International Human Rights Law M.A. at the American University in Cairo, DCL candidate, McGill, and J.D., Harvard Law School. I would like to thank the McGill CHRLP and its associated faculty for their support and acknowledge the importance of having been granted an O'Brien Fellowship for getting this article ready for publication. Specifically, I would like to thank Colleen Sheppard for the invitation to present this paper and for her comments at the Annie MacDonald Langstaff lecture along with Frédéric Megret for his encouragement. Thank you especially to Alex Lorite for his many comments on various drafts and his unwavering support. Finally, I would like to thank Martti Koskenniemi for his generosity in taking the time to comment on a very early draft. Any errors are my own.
}

1 Convention on the Elimination of All Forms of Discrimination against Women, Dec. 18, 1979, 1249 U.N.T.S. 13 (entered into force Sept. 3, 1981) [hereinafter CEDAW]. 
or modify the legal effect of a treaty on the reserving state. ${ }^{2}$ Reservations to multilateral human rights treaties have been considered contentious because individual states enter reservations modifying treaty application not only between themselves and other state parties to the treaty, but also between themselves and individuals under the jurisdiction of the reserving state. This has been seen as effectively tailoring the meaning or application of human rights for individuals and groups within a state according to that state's will.

CEDAW, an international treaty agreed upon among states, creates obligations for states to eliminate all formal discrimination against women, but also requires them to take steps to ensure that women are able to enjoy their basic human rights fully and on an equal footing with men. Due in part to the high number of states which entered reservations to CEDAW, reservations to this treaty have become particularly contentious. The mainstream human rights position on reservations, developed in the 1990s within legal debates about international human rights law in general, maintains that reservations entered by state parties to CEDAW are, generally speaking, a problem for women and should be dealt with as such, that is, as being in principle in contradiction with the Convention itself. State parties who entered reservations, however, based their position on the consensual nature of international treaty making, invoking their sovereign right to enter reservations to any treaty that does not formally prohibit such reservations. A dominant progressive position on women's rights thus emerged, which maintained that the Shari'a based reservations, especially those to Article 2 of CEDAW, ${ }^{3}$ are incompatible with the object and purpose of

2 Vienna Convention on the Law of Treaties, art. 2.1(d), opened for signature May 23, 1969, 1155 U.N.T.S. 331 [hereinafter Vienna Convention].

3 Article 2 states:

States Parties condemn discrimination against women in all its forms, agree to pursue by all appropriate means and without delay a policy of eliminating discrimination against women and, to this end, undertake:

(a) To embody the principle of the equality of men and women in their national constitutions or other appropriate legislation if not yet incorporated therein and to ensure, through law and other appropriate means, the practical realization of this principle;

(b) To adopt appropriate legislative and other measures, including sanctions where appropriate, prohibiting all discrimination against women;

(c) To establish legal protection of the rights of women on an equal basis with men and to ensure through competent national tribunals and other public institutions the effective protection of women against any act of discrimination;

(d) To refrain from engaging in any act or practice of discrimination against women and to ensure that public authorities and institutions shall act in conformity with this obligation;

(e) To take all appropriate measures to eliminate discrimination against women by any person, organization or enterprise; 
the treaty and are thus, under international law, impermissible. ${ }^{4}$

The debate over the Shari'a based reservations can be understood as a concrete example of what some have viewed as a necessary clash between international law and Islamic law, or the issue could be addressed as an opportunity to rethink the relationship between the two, and to find a way to mediate a false opposition. ${ }^{5}$ This paper addresses how a dominant international human rights position on reservations, which assumes that human rights law and Islamic law are both internally coherent and in conflict with one another, may contribute to the production of a false opposition with paradoxical consequences. This conflict could arguably be making it more difficult to produce internally generated dissent within Muslim-majority countries that utilize Islamic Shari'a as a primary source of law, as well as producing an exclusionary and therefore deficient human rights discourse for progressive social and political forces.

In the following sections I address how the issue of reservations to CEDAW has become the location for the crystallization of several latent conflicts in international law. I trace some of the ways in which the debate over the permissibility of Shari'a reservations is based on disagreements about the nature of international law, about feminist theory in women's rights, about how religion and gender could or should be constituted through the state, and about who the proper subject of rights should be.

(f) To take all appropriate measures, including legislation, to modify or abolish existing laws, regulations, customs and practices which constitute discrimination against women;

(g) To repeal all national penal provisions which constitute discrimination against women.

CEDAW, supra note 1 , at 16 .

4 Article 19 of the Vienna Convention provides:

A State may, when signing, ratifying, accepting, approving or acceding to a treaty, formulate a reservation unless:

(a) the reservation is prohibited by the treaty;

(b) the treaty provides that only specified reservations, which do not include the reservation in question, may be made; or

(c) in cases not failing under subparagraphs (a) and (b), the reservation is incompatible with the object and purpose of the treaty.

Vienna Convention, supra note 2, at 336-37.

5 See, e.g., Abdullahi A. An-Na'im, Islam and International Law: Toward a Positive Mutual Engagement to Realize Shared Ideals, 98 Am. Soc'y InT'L L. Proc. 159, 160 (2004). 
After establishing the theoretical orientation of the argument in the following section, Part I will examine how parties to CEDAW, as well as United Nations (UN) human rights experts entrusted with monitoring CEDAW's application, have attempted to constrain states through the treatment of Shari'a based reservations. In Part II, I look at the reservations debate as a prism that makes visible the way in which women's rights have at times been constructed on the assumed necessity for secularism, and the concurrent compulsion to push religion out of the public sphere and into the private domain.

Throughout the paper, the critique rests on the competing assumption that we need not fall prey to moral relativism or give up on women's universal empowerment simply because we may want to allow for diversity in women's rights. However, by painting Islamic law and human rights with broad strokes as coherent, homogeneous and singular, and creating bright lines along the public/private distinction, some international law advocates and scholars have contributed to a contrived opposition that may have damaged the legitimacy of international human rights law as a vehicle for universal human emancipation and progress.

\section{B. Women's Rights: A Theoretical Framework}

At one point the privileging of liberal feminism over other traditions contributed to the creation and structure of the opposition between international law and Islamic law, as it fit easily within a rights framework. ${ }^{6}$ This is because feminism, as a politically and theoretically heterogeneous position, had for a time at least become unpalatable in comparison to the more apparently neutral and comprehensible discourse of women's rights. That is to say, it is much more difficult to assert one's opposition to women's rights than to feminism. So, as the discourse of women's rights took over the academic and policy fields of gender, purging them of some explicitly feminist positions and theoretically rich traditions, it should not be surprising that feminist methodology had, at least for a time, fallen out of fashion. ${ }^{7}$ The mainstreaming of gender in international relations may have exacerbated this

6 The complicated relationship between various strands of feminisms and the general framework of human rights is examined in analytic and historical terms in Karen Engle, International Human Rights and Feminism: When Discourses Meet, 13 Mich. J. INT’L L. 517 (1992).

7 In the age of women's rights, it seems that conventional wisdom would have us replace the politically divisive feminist movement with an apparently less politically charged women's rights discourse. Dianne Otto's 2013 edited three volumes on GeNDER Issues AND Human Rights highlight the transformation in the field as a representative collection of gender and human rights from the 1970s to the present. Sometime around 1999 feminism stopped being mentioned as much, just as "gender analysis" became a more commonplace reference. Some of the authors in the collection are themselves critical of the transformation, though in different terms. See generally, Gender Issues and Human Rights (Dianne Otto ed., 2013). For an account of the generational 
process as gender analysis became an empirical endeavor of counting women, and women's empowerment became reducible to merely adding female bodies within institutions. ${ }^{8}$ More dramatically, the radical nature of CEDAW may have been defanged in the global North by the sacrosanct value of individual freedom as supposedly private choices of women comprising gender differences between women and men have been granted a veil of protection. ${ }^{9}$ Without the vibrant debate that differing feminist positions produced, and the very different insights of those positions, the gender discourse in international relations has veered toward methodological abstinence and political dogmatism. ${ }^{10}$ However, rather than "taking a break from feminism" 11 in the age of women's rights, a moment in which women are increasingly regulated by law, committed political positions on gender in law that explicitly employ feminist methodologies should be discussed, theorized, and

gap in feminism more generally, as far as the American context in concerned, see Susan Faludi, American Electra: Feminism's Ritual Matricide, HARPER's MAGAZINE, Oct. 2010, at 29. For a discussion of the continuities and ruptures in the evolution of late twentieth-century feminism, see, e.g., the collection of essays in THIRD Wave Feminism: A Critical Exploration (Stacy Gillis et al. eds., 2004). For an argument strengthening the positions against feminism in law see, e.g., Janet Halley, Split Decisions: How and Why to Take a Break FROM FEMINISM (2006).

8 Hilary Charlesworth, Not Waving but Drowning: Gender Mainstreaming and Human Rights in the United Nations, 18 Harv. Hum. RTs. J. 1 (2005).

9 The link between women's private choices and women's empowerment is complex and there are no simple answers in the global North or South. For analysis of the difficulty and contradictions in the ways in which women's choices are constructed in the global North, see generally Angela CAmpbell, Sister Wives, SurRogates And Sex Workers (2013). My argument presently is that women in the North are treated differently from women in the South and the different treatment often revolves around questions of choice. This of course elides many of the subcategories of women in the North and South alike. The differences between categories of women affects the way in which legal institutions construct their agency and certain categories of women in the North will be constructed similarly to women in the South. That is, what they say about their choices may be ignored if they are women of color or women engaged in sex work. It can be explained as a way of understanding the periphery relative to the center in both contexts.

10 A point of reference in feminist international law and international relations is Security Council Resolution 1325, of 31 October 2000, on women, peace, and security. See Nadine Puechguirbal, Discourses on Gender, Patriarchy and Resolution 1325: A Textual Analysis of UN Documents, 17 INT'L PeAceKeEPING 172 (2010).

11 This is the position championed by Janet Halley. See, e.g., Brenda Cossman et al., Gender, Sexuality, and Law: Is Feminism Enough?, 12 Colum. J. Gender \& L. 601, 604 (2003) ("I am here to sell you the idea that Taking a Break from Feminism is a good thing to do."); Janet Halley, Queer Theory by Men, 11 DuKE J. GenDER L. \& PoL'Y 7 (2004) ("In this essay I present parts—not all—of my argument that it would be good for left prosex intellectual and political work, including feminist work of this kind, if people doing it could occasionally Take a Break from Feminism."); Janet Halley, Take a Break from Feminism, in Gender AND Human Rights 57 (Karen Knop ed., 2004). And more generally, HaLleY, supra note 7. 
acted upon. ${ }^{12}$ While we are currently witnessing a renaissance of feminism, what it will ultimately look like is yet to be determined. We can only hope that this new wave of feminism will be an open, large-tent discourse that is capable of empowering women and seeing beyond our own subject positions while not silencing marginal voices. In the area of international women's rights, there is a need to revisit human rights dogma and push back against mainstream dominant positions that deal with gender oppression superficially. This requires conceptual shifts in the categories that have dominated the mainstream debate in the field. In this context, it is not surprising that there is something problematic about the way in which the debate in women's rights has played out around the issue of Islamic law and gender oppression.

In the field of international women's rights, and specifically when talking about women in the Middle East, an opposition was set up in the 1990s and was put rather pointedly by Ann Elizabeth Mayer: "There are two basic positions one can take on women's rights, the universalist and the cultural relativist ... according to the universalist position, all women are entitled to the rights set forth in international covenants . . relativists argue that members of one society may not legitimately condemn the practices of societies with different traditions ...." "13 This opposition has been given more nuance over the years by Mayer herself and others. Instead of arguing simply that women's rights are universal, the claim is rather that relativist arguments do not constitute a legitimate defense for the oppression of women, while at the same time that the defense of human rights cannot be

12 Proponents of this position include, for example, Brenda Cossman and Robin West. However, there also seems to be a generational gap as new voices do not employ varied feminist methodologies as much as liberalism through a women's rights approach. On the institutional shift to women's rights, see, e.g., Sylvia Walby, Feminism in a Global Age, 31 Econ. \& Soc'y 533 (2002). Perhaps some of this shift is due to a feminist opt-out by theorists to self-categorize and theorize under Queer theory. However, the argument for queer theory in lieu of feminist theory seems unreasonably restrictive. Cognizant that theories can reify concepts, feminist theory is not necessarily at odds with queer theory, since it is even possible to employ different analyses at different times. See, e.g., Brenda Cossman, Sexuality, Queer Theory, and "Feminism After:" Reading and Rereading the Sexual Subject, 49 McGill L. R. 847 (2008). On West's position vis-à-vis queer theory, see Robin West, Sex, Law and Consent, in The Ethics of Consent: Theory and Practice 221 (Alan Wertheimer \& Franklin Miller eds., 2010). See also the exchange between West and Halley: Janet Halley, The Politics of Injury: A Review of Robin West's Caring for Justice, 1 Unbound 65 (2005) and Robin West, Desperately Seeking a Moralist, 29 Harv. J.L. \& Gender 1 (2006).

13 Ann Elizabeth Mayer, Cultural Particularism as a Bar to Women's Rights: Reflections on the Middle Eastern Experience, in Women's Rights, Human Rights: International Feminist Perspectives 176 (Julia Peters \& Andrea Wolper eds., 1995). You can trace a discursive progression in the way in which the argument against Islamic reservations has become more nuanced and less blatant but remains largely the same by comparing Mayer's early work in the 1990s to the most recent edition, ANN ElizABETH MAYER, Islam AND HuMAN Rights: Tradition And Politics (5th ed. 2013). 
grounded in ethnocentric reasoning. ${ }^{14}$ The attempt to reconcile the particularity of local contexts and a universal discourse appears to be one of the many challenges the U.N. faces.

The universality of human rights and their validity in a given local context have often been contested through relativist discourses that brand them as foreign ideas incompatible with local culture. However, the Special Rapporteur in the field of cultural rights has warned against discourses that disregard the fact that culture is not static and changes over time. ... The Special Rapporteur on violence against women, in her report on intersections between culture and violence against women, argues that it is possible to negotiate human rights with culture, challenging discriminatory and oppressive aspects of culture while retaining its positive aspects. ${ }^{15}$

The question is how the negotiation between human rights and culture works out in the details of particular issues. Despite decades in which Third World and Critical Race feminists have critiqued the line according to which there is one single female viewpoint, the debate in human rights continues to grapple with the opposition between women's rights and cultural rights. ${ }^{16}$ The complexity of the theoretical issues may result in the persistence of some of the less nuanced approaches to women's rights. Some advocates of women's rights still believe that, for women's human rights to be meaningful, there cannot be deviation from a single universal. ${ }^{17}$ This position tends to assume the tenets of liberal feminism as a singular ideology behind women's rights, bankrupting the discourse in its blindness to power dynamics functioning in conjunction with gender discrimination.

The women's rights discourse has been built on the elision of certain binaries made historically visible by feminist theory. Foregrounding these old binaries allows us to relinquish frustration with the international process through the generation of a new set

14 United Nations Office of the High Comm'r for Human Rights, Women's Rights are Human Rights 28, U.N. Doc. HR/PUB/14/2 (2014), http://www.ohchr.org/Documents/Publications/HR-PUB-14-2.pdf [perma.cc/ F2JX-YXQB].

\section{Id. at 28-29.}

16 To understand the particular difficulties of intersectionality and culture, see, e.g., Maneesha Deckha, Is Culture Taboo? Feminism, Intersectionality, and Culture Talk in Law, 16 CAN. J. Women \& L. 14 (2004).

17 See, e.g., Johanna Fournier, Reservations and the Effective Protection of Human Rights, 2(2) GoETTINGEN J. INT'L L. 437, 457 (2010). 
of conceptual categories. ${ }^{18}$ Procedurally, the argument requires accepting in principle reservations to human rights treaties, while conceptually it provides liberation from blind spots produced by the failure to employ feminist insights. For renewal of the feminist project in international law, it is imperative to destabilize many of the binaries found in international human rights law. ${ }^{19}$ Rejecting the false choice between human rights as the instantiation of universalism and some undefined particularism/localism/relativism results from foregrounding other binaries in the debate, such as North/South and public/private. Most importantly, methodologically, it requires that we make the familiar exotic, or rather that the mainstream be measured against the periphery. In revisiting the reservations debate, one preconception held onto is that, following Boaventura de Sousa Santos, it is possible to be politically engaged and an advocate against the oppression of women, and to be an advocate for women's rights without committing what he calls "epistemicide" through the imperialistic deployment of human rights. ${ }^{20}$ The reservations debate is one discursive space, one area in which concrete legal mechanisms exist with which women's rights and culture can be negotiated.

\section{Broad Strokes: Constraining Shari'a Based Reservations}

\section{A. Reservations and the Law of Treaties}

In 2011, the International Law Commission (ILC) concluded the Guide to Practice on Reservations to Treaties. Although it is not a binding source of law, the Guide provides

18 See, e.g., Frances E. Olsen, The Myth of State Intervention in the Family, 18 U. Mich. J.L. Reform 835 (1985). What is new in revisiting these old projects and binaries is that I am arguing that there has been a shift in the normative valence of these old binaries in the field of women's rights. As Karen Engle noted in 1993, there was an assumption among feminists that the private needed to be scrutinized for women's empowerment. Karen Engle, After the Collapse of the Public/Private Distinction: Strategizing Women's Rights, 25 Stud. Transnat'L L. PoL'y 143 (1993) (arguing in 1993 that the distinction and these assumptions had run their course in the debate and there needed to be a change in focus for women's rights to move forward.) I am arguing that currently the women's rights movement ignores the way religion is constituted by law, and gender oppression is once again being pushed into the private sphere. The exception to this rule is the issue of violence against women. The women's rights movement is focused uniquely on private violence against women as an issue that was specifically addressed by radical feminists such as Catherine Mackinnon. See Catherine Mackinnon, On Torture: A Feminist Perspective on Human Rights, in Human Rights in the Twenty-First Century: A Global Challenge 21 (Kathleen Mahoney \& Paul Mahoney eds., 1993).

19 Dianne Otto, International Human Rights Law: Towards Rethinking Sex/Gender Dualism and Asymmetry, in A Research Companion to Feminist Legal Theory 197 (Margaret Davies \& Vanessa Munro eds., 2013).

20 Boaventura de Sousa Santos, Another Knowledge Is Possible: Beyond Northern Epistemologies xix (2007). 
legal guidance to the international community. It addresses the many problems surrounding reservations in the law of treaties and specifically the "problem" of reservations to human rights treaties. The ILC has a very particular way of dealing with the Shari'a reservations. It must be read in part as being a product of compromise in various debates.

In their most recent incarnations, the debates over reservations have led to a reexamination of the very nature of international law in its relationship to human rights treaties. ${ }^{21}$ The question has been posed whether human rights law is "regular" international law, with the contractual characteristics of the Vienna Convention, or whether human rights treaties have a special character which invokes a different kind of norm to protect something like a global community's interests. ${ }^{22}$ Within the law of treaties, it is clear that reservations are permitted unless explicitly specified or they are otherwise not compatible with the object and purpose of the treaty. ${ }^{23}$ However, the reservations made to human rights treaties, as a category, have been challenged on the basis that they form an obstacle to the complete implementation of a human rights system. They have been put into question in various ways claiming that they challenge the makeup and integrity of the human rights system. ${ }^{24}$ Reservations have been said to turn any human rights treaty into nothing

21 Alain Pellet has dealt extensively with this problem when dealing with the issue of reservations to treaties in his private work and the reports he has submitted to the ILC as Special Rapporteur. See e.g. Alain Pellet, Article 19: Formulation of Reservations, in 1 The Vienna Conventions on the LaW of Treaties: A Commentary 405 (Olivier Corten \& Pierre Klein eds., 2011); Alain Pellet \& Daniel Muller, Reservations to Human Rights Treaties: Not an Absolute Evil, in From Bilateralism to Community Interest-Essays in Honour of Judge Bruno Simma 521 (Ulrich Fastenrath et al. eds., 2011); Alain Pellet, Reservations to Treaties and the Integrity of Human Rights, in The Routledge Handboook of International Human Rights Law 323 (Nigel Rodley \& Scott Sheeran eds., 2013). See also Martin Scheinin, Impact on the Law of Treaties, in The IMPACT OF Human Rights Law on General International Law 23 (Menno T. Kamminga and Martin Scheinin eds., 2009). On the topic of human rights exceptionalism more generally see Scott Sheeran, The relationship of international human rights law and general international law: hermeneutic constraint, or pushing the boundaries?, in THE Routledge Handboook of International Human Rights Law 39 (Nigel Rodley \& Scott Sheeran eds., 2013).

22 The assertion of a special status for human rights law triggered the known polemic led by Alain Pellet, under the heading of "human rightism" ("droit de l'hommisme"), against a perceived quest for human rights exceptionalism in international law. See, e.g., Alain Pellet, "Human Rightism" and International Law, 10 ITALIAN Y.B. INT’L L. 3 (2000).

23 Vienna Convention, supra note 2, at art. 19. Though reservations are permitted, this is not an unproblematic formulation. See Jan Klabbers, Some Problems Regarding the Object and Purpose of Treaties, 8 FinN. Y.B. INT’L L. 138 (1998).

24 See Rosalyn Higgins, The United Nations: Still a Force for Peace, 52 Mod. L. Rev. 1, 12 (1989). Higgins views reservations as a challenge to the integrity of the human rights system. 
more than a "moth-eaten guarantee." ${ }^{25}$ Some commentators have gone as far as to claim that reservations have already "eroded the basis for modern international human rights protection." ${ }^{26}$

Within traditional approaches to international law, reservations are not regarded as per se undesirable. ${ }^{27}$ The "problem" of reservations to so-called norm generating treaties has been an issue of complexity for international lawyers for the latter part of the twentieth century. The issuance of the split advisory opinion of the International Court of Justice (ICJ) in the 1951 Genocide Opinion initiated a new phase in the controversy. ${ }^{28}$ In the nineteen eighties the continually "thorny and controversial issue" ${ }^{29}$ of reservations surfaced again among women's right advocates with the ratifications and entry into force of the Convention on the Elimination of all Forms of Discrimination against Women (CEDAW), which came to have a particularly high number of reservations. ${ }^{30}$ And again, in 1994 after the issuance of General Comment 24 by the Human Rights Committee, ${ }^{31}$ the "problem" of reservations reemerged as a controversial issue among legal scholars, practitioners, United Nations agencies and state policy makers. ${ }^{32}$

25 Liesbeth Lijnzaad, Reservations to UN Human Rights Treaties: Ratify and Ruin? 3 (1995).

26 Roslyn Moloney, Incompatible Reservations to Human Rights Treaties: Severability and the Problem of State Consent, 5 Melbourne J. InT’L L. 155, 156 (2004).

27 Vienna Convention, supra note 2. See also Anthony Aust, Modern Treaty LaW and Practice 133 (2d ed. 2007) (according to Aust, "[t] $]$ here is nothing inherently wicked or even undesirable in formulating a reservation to a multilateral treaty").

28 Reservations to the Convention on the Prevention and Punishment of the Crime of Genocide, Advisory Opinion, 195 I.C.J. Rep. 15 (May 28).

29 Alain Pellet (Special Rapporteur on Reservations to Treaties), Seventh report on reservations to treaties, U.N. Doc. A/CN.4/526, at 4, ๆ 11 (2002) (quoting Paul Reuter). See also Paul Reuter (Special Rapporteur), Tenth report on the question of treaties concluded between States and international organizations or between two or more international Organizations, [1981] 2 Y.B. of THE INT'L L. Commission 56, U.N. Doc. A/CN.4/ SER.A/1981/Add.1 (Part 1), \53.

30 Belinda Clark, The Vienna Convention Reservations Regime and the Convention on Discrimination Against Women, 85 Aм. J. INT’L L. 281, 282, 306 (1991).

31 U.N. Human Rights Committee, General Comment No. 24, Reservations to the ICCPR, U.N. Doc. CCPR/C/21/Rev.1/Add.6 (Nov. 4, 1994) [hereinafter General Comment No. 24].

32 Catherine J. Redgwell, Reservations to Treaties and Human Rights Committee General Comment No. 24 (52), 46(2) InT'L \& Comp. L. Q. 390 (1997); Ulf Linderfalk, Reservations to Treaties and Norms of Jus Cogens - A Comment on Human Rights General Comment No. 24, in Reservations to Human Rights Treaties and the Vienna Convention Regime 213 (Ineta Ziemele ed., 2004). 
More recently, in 2006, the ICJ delivered its judgment on jurisdiction and admissibility in the case concerning Armed activities on the territory of the Congo opposing the Democratic Republic of the Congo (DRC) to Rwanda. ${ }^{33}$ In this case, the DRC sought to invoke the jurisdiction of the ICJ on the basis of (among other treaty provisions) Article 22 of Convention on the Elimination of All Forms of Racial Discrimination (CERD), ${ }^{34}$ while Rwanda argued that the ICJ had no jurisdiction as it was precluded by its reservation to Article $22 .{ }^{35}$ The ICJ found that they had no jurisdiction in the case, as two-thirds of the state parties had not objected to the reservation. Again, the ICJ found that they also did not have jurisdiction under the Genocide Convention as Rwanda had a reservation precluding the ICJ's jurisdiction. The ICJ found that this reservation was not incompatible with the object and purpose of the treaty. In a joint separate opinion, Judges Higgins, Elaraby, Kooijmans, Owada, and Simma observed that since the 1951 opinion there have been many developments in international law that could not be taken into consideration, including the creation of human rights treaties which have monitoring bodies-something seemingly unique to the human rights treaties. The Judges note that the work of the treaty bodies should "not be viewed as 'making an exception' to the law as determined in 1951 by the International Court," and declare further: "We take the view that it is rather a development to cover what the Court was never asked at the time, and to address new issues that have arisen subsequently." ${ }^{" 36}$ The ICJ asserts that there is no schism in international law. By both asserting the unique characteristics of human rights treaties and the unity and coherence of international law, the ICJ attempts to placate both the traditionalists in international law and those looking for new interpretations for the purpose of furthering social justice.

Placating opposing groups has done little to settle the question. This opinion did not quell the controversy over reservations. Instead of settling the issue, there has been a proliferation of working groups, reports and academic articles working out the "problem" of reservations since the ICJ issued their opinion, despite the appointment of the Special Rapporteur, Alain Pellet, and draft reports issued by the ILC. ${ }^{37}$ The religious zeal with

33 Armed Activities on the Territory of the Congo (Democratic Republic of the Congo v. Rwanda), Judgment, 2006 I.C.J. Rep. 6. (Feb. 3).

34 Id. at 33.

35 Id. at 34.

$36 I d$. at 69 (Joint Separate Opinion of Higgins, Kooijmans, Elaraby, Owada, and Simma, JJ.).

37 Conventional wisdom in the discipline is that the ICJ did not add anything new to the ongoing and established debate about reservations. This is highlighted in particular in the judgment's reception by the Special Rapporteur of the ILC on reservations to treaties. See Alain Pellet (Special Rapporteur on Reservations to Treaties), Eleventh report on reservations to treaties, at 13, qा 44 et seq., U.N. Doc. A/CN.4/574 (2005). 
which various sides debate the issues over reservations suggests something about the nature of the controversy and what is perceived to be at stake. The choice between the universal and the particular both animates and constrains the debate.

In the field of human rights, reservations are often treated categorically. ${ }^{38} \mathrm{As}$ a category, any "exclusion" or "modification" of the "legal effect" 39 of a human rights treaty meeting the legal definition of a reservation is regarded with suspicion and contempt among many in the field of human rights law irrespective of the specifics of the reservation in question. ${ }^{40}$ Indeed, as Alain Pellet has noted, attitudes regarding reservations take on an almost religious zeal whether one is either for or against reservations in relation to human rights treaties. ${ }^{41}$

There are several things that the Guide to Practice on Reservations to Treaties does to clarify the many difficulties surrounding reservations to treaties. First, it should be noted, as the Special Rapporteur did, that nowhere in the Guide is there special mention of human rights treaties. In the new interpretation, human rights treaties are treated exactly the same as any other kind of treaty. This is significant since as stated before, much of the debate over

Criticism of the judgment has been polarized along equally familiar lines. See Dan Hammer, Allowing Genocide? An Analysis of Armed Activities on the Territory of the Congo, Jurisdictional Reservations, and the Legitimacy of the International Court of Justice, 16 MinN. J. OF INT'L L. 495 (2007); Alexander Orakhelashvili, Case Concerning Armed Activities on the Territory of the Congo (DRC v Rwanda), Jurisdiction and Admissibility, Judgment of 3 February 2006, 55 InT'L \& ComP. L.Q. 753 (2006).

38 There are larger questions regarding the structure and nature of human rights law. For example, whether or not human rights law is "regular" law. These questions are beyond the scope of this paper, i.e. the issue of reservations to human rights treaties. See Matthew Craven, Legal Differentiation and the Concept of the Human Rights Treaty in International Law, 11 EuR. J. INT'L L. 489 (2000).

39 Vienna Convention, supra note 2, at art. 2.

40 For examples of this more or less explicit so-called reservation regarding reservations to human rights treaties, see, e.g., Edward T. Swaine, Reserving, 31 YALE J. InT'L L. 307 (2006); Yogesh Tyagi, The Conflict of Law and Policy on Reservations to Human Rights Treaties, 71 BRIT. Y.B. INT'L L. 181 (2001). See also Reservations to Human Rights Treaties and the Vienna Convention Regime: Conflict, Harmony or Reconciliation (Ineta Ziemele ed., 2004); Jean Koh Peters, Reservations to Multilateral Treaties: How International Legal Doctrine Reflects World Vision, 23 Harv. InT'L L. J. 71 (1982); Konstantin Korkelia, New Challenges to the Regime of Reservations Under the International Covenant on Civil and Political Rights, 13 Eur. J. INT'L L. 437 (2002); Linderfalk, supra note 32; Eric Neumayer, Qualified Ratification: Explaining Reservations to International Human Rights Treaties, 36 J. Leg. Stud. 397 (2007); Roberto Baratta, Should Invalid Reservations to Human Rights Treaties Be Disregarded?, 11 Eur. J. INT’L L. 413 (2000).

41 Alain Pellet \& Daniel Müller, Reservations to Human Rights Treaties: Not an Absolute Evil . . , in From Bilateralism to Community Interest: Essays in Honour of Bruno Simma 521, 522 (Ulrich Fastenrath et al. eds., 2011). 
reservations to human rights treaties had been over the exceptional status of human rights norms and the supposed way in which the treaties have non-reciprocal relationships and protect individuals as opposed to purely or clearly the interests of the states involved. The Guide has weighed in on the question of the non-exceptional nature of international human rights law. I would argue that the treatment of the Shari'a reservations were a means to get to that end. The Guide also reaffirms state parties' absolute right to formulate reservations to treaties including human rights treaties. They must still meet all the requirements of Article 19 of the Vienna Convention, but the ILC has reaffirmed the position that reservations to human rights treaties are not problematic in themselves.

On the topic of "Islamic reservations," or "shari'a reservations" as Professor Pellet typically calls them, he claimed that they are not a problem because they are derived from religious law, or because they are in fact contrary to the object and purpose of a treaty, they are a problem because they are overly vague and general. ${ }^{42}$ Professor Pellet specified that the problem of vague reservations is that states cannot object to these reservations because their meaning is unclear and so it is not possible to assess the compatibility with the object and purpose of the treaty. ${ }^{43}$ There is nothing in the text of the Vienna Convention precluding vague or general reservations. It appears that the ILC has borrowed this guideline from the European Convention on Human Rights, which has an explicit article precluding vague or general reservations. ${ }^{44}$ Pellet has noted that this was a non-controversial way to deal with what had been a very contentious issue ${ }^{45}$ Although it was diplomatically astute and legally witty, it is potentially problematic in terms of how states will react to this interpretation. ${ }^{46}$ States are in a position now to harden their reservations and make them more specific now that it has been confirmed that reservations to human rights treaties are not necessarily a problem. State parties along with the CEDAW Committee are now in a position to decide individually how to read and implement the Guide. It is precisely in this moment, following the release of the Guide, that a rereading of the debate over these controversial reservations and of international law's relationship to Islamic law should be revisited. The following section will address how the reservations and patterns of state objections unfolded and

42 U.N. Report of the International Law Commission, 63rd Sess., U.N. Doc. A/66/10 (2011).

43 Id. See also Alain Pellet, The ILC Guide to Practice on Reservations to Treaties: A General Presentation by the Special Rapporteur, 24 EuR. J. INT’L L. 1061, 1097 (2013).

44 European Convention on Human Rights, Nov. 4, 1950, E.T.S. 5, art. 57.

45 Pellet, ILC Guide to Practice on Reservations to Treaties, supra note 43, at 1097.

46 See Tanya Monforte, The Permissibility of Vague or General Reservations: The ILC's Treatment of Shari'a Reservations (unpublished article) (on file with author). 
created the current context.

\section{B. Islamic Reservations and State Objections}

It has been noted that CEDAW is the human rights treaty "most affected by reservations." ${ }^{\text {"47 }}$ There are many reservations to the Convention, to be sure, but the term "affected" can mean different things. What it means in the context of women's rights, in relation to the issue of the reservations made primarily by Islamic states, is that reservations have been hotly contested along ideological lines leading to deep rifts in the international community. ${ }^{48}$

47 International Human Rights Instruments, Rep. of the Meeting of the Working Group on Reservations, U.N. Doc. HRI/MC/2007/5, at 4, 1 14. (Feb. 9, 2007).

48 Aust, supra note 27, at 133 ("The problem of the legal effect of objections is the same for all multilateral treaties, it is just that the problem occurs more often, and more acutely, with human rights treaties because they have to reconcile not just different national policies, but different religious and social systems."). The peculiar position of the issue of reservations by "Islamic States" in the general question of treaty reservations is noted e.g. in Baratta, supra note 40, at 424 n.42. See also Zehra F. Kabasakal Arat, Promoting Women's Rights against Patriarchal Claims: The Women's Convention and Reservations by Muslim States, in Global Human Rights Norms: Area Studies Revisited 231 (David Forsythe \& Patrice McMahon eds., 2003).

In response to Aust, one should note that there are least two other legal debates that have prompted the peculiar visibility of reservations to human rights treaties in the past two decades. One is the already noted involvement of the ICJ in issues relating to reservations to human rights treaties in the context of systematic human rights violations and genocide. See, e.g., Application for Revision of the Judgment of 11 July 1996 in the Case concerning Application of the Convention on the Prevention and Punishment of the Crime of Genocide (Bosnia and Herzegovina v. Yugoslavia), Preliminary Objections (Yugoslavia v. Bosnia and Herzegovina), Judgment, 2003 I.C.J. Rep. 7, at 24-25, $\uparrow 52$ (Feb. 3) (discussing the introduction by Yugoslavia of a reservation to Article IX of the Genocide Convention at the time of newly ratifying it after Yugoslavia's admission to the United Nations); Application of the Convention on the Prevention and Punishment of the Crime of Genocide (Croatia v. Serbia), Preliminary Objections, Judgment, 2008 I.C.J. Rep. 414, at 444, qฯ 94 et seq. (Nov. 18) (discussing the same issue as in the preceding case, and its effect with regards to Croatia's claims against Yugoslavia); Application of the Convention on the Prevention and Punishment of the Crime of Genocide (Bosnia and Herzegovina v. Yugoslavia), Judgment, 2007 I.C.J. Rep. 47, at 93-102, 9甲 121-41 (Feb. 26) (closing the debate over Yugoslavia's reservation to Article IX of the Genocide Convention by invocation of the res judicata principle in reference to its 1996 Judgment on Preliminary Objections and 2003 Judgment on Yugoslavia Application for the revision of the 1996 Judgment).

Another line has been the particular attention given to treaty reservations and declarations made by the United States, either to human rights treaties (like ICCPR or CAT) or to other treaties with alleged human rights implications. See generally Curtis Bradley \& Jack Goldsmith, Treaties, Human Rights and Conditional Consent, 149 U. PA. L. R. 399 (2000); Ryan Goodman, Human Rights Treaties, Invalid Reservations, and State Consent, 96 Am. J. InT’L L. 531 (2002). 


\section{Patterns of State Objections to Shari'a Reservations}

Reservations to CEDAW have prompted discussion and analysis from commentators since the early $1990 \mathrm{~s} .{ }^{49}$ During the first round of ratifications of CEDAW a conflict emerged over the reservations submitted by Egypt and Bangladesh, which were then objected to by a handful of European countries, as well as by Mexico. A conflict emerged as "Western" states were accused of promoting an un-Islamic position..$^{50}$ As Belinda Clark put it, "Islamic countries accused Western countries of cultural insensitivity and interference with their sovereign right to make reservations. ${ }^{, 1}$ Since 2000, the geographical divide and pitting of Islamic states against European states has only become starker. Several new states have ratified CEDAW with reservations referring to Islam or Islamic Shari'a, and European states have systematically - and in an apparently coordinated fashion - objected to these reservations, while leaving sweeping reservations of a non-religious character untouched. ${ }^{52}$

The volatile issue of the regulation of women under Islamic law extends far beyond the issue of treaty reservations. But it is not a coincidence that it was precisely in the context of CEDAW that a controversy set off a deeply felt debate cast in polarizing binaries in, of all places, the law of treaties. CEDAW is, obviously enough, an important site for debate on social, economic and cultural policy. It is the site, within the international liberal framework, where the tensions in the treatment of women and the treatment of religion, between the so-called "universal" and "particular" in human rights, play out. ${ }^{53}$ What is perhaps surprising, at least to some, is that the debate is here couched in the hyper-technical language of the law of treaties. ${ }^{54}$

49 See, e.g., Rebecca J. Cook, Reservations to the Convention on the Elimination of All Forms of Discrimination Against Women, 30 VA. J. InT'L L. 643 (1990); Clark, supra note 30; Vedna Jivan \& Christine Forster, What Would Gandhi Say-Reconciling Universalism, Cultural Relativism and Feminism Through Women's Use of CEDAW, 9 Singapore Y. B. INT'L L. 103 (2005); Jennifer Riddle, Making CEDAW Universal: A Critique of CEDAW's Reservation Regime under Article 28 and the Effectiveness of the Reporting Process, 34 Geo. Wash. InT’L L. Rev. 605 (2002); Johanna Fournier, supra note 17, at 437.

50 "Western" is in quotes to note the use of the distinction between the West and "the rest," while intending to avoid reification of these categories with their use. See Clark, supra note 30, at 284.

51 Id. at 287. See also Eva Brems, Human Rights: Universality and Diversity 267-70 (2001).

52 See the complete text of the reservations and objections on the website of the U.N. Treaty Collection at Multilateral Treaties Deposited with the Secretary-General, U.N. TREATY Collection, http:/treaties.un.org/ Pages/Treaties.aspx?id=4\&subid=A\&lang=en [perma.cc/RS5J-FJ85].

53 Martha C. Nussbaum, Sex and Social Justice 84 (1999).

54 There are several disciplines in which similar debates are played out, but in most, such as in philosophy, 
There is little point in fully rehearsing the claim that objecting states were applying a double standard by objecting to "Islamic reservations" while allowing other state reservations to stand, without an argument to support the discriminating stance. One simply notes that Spain makes objections to "Islamic" reservations while it maintains a declaration that aims at securing legally a male heir for the monarchy-which constitutes an important and symbolic departure from gender equality. One can simply say that European reservations aiming at the maintenance of discrimination against women (as opposed to temporary measures favoring women) are not answered by any objection from the usual (European) objectors. European traditions are left intact. In fact, with the exception of France, European countries objecting to the "Islamic reservations" have not felt personally compelled to withdraw their own reservations. France is an exception as it did withdraw all of its reservations recently. For states at least, it appears that the offense is not constituted by reservations as such, but rather by the particular reservations made by Muslim-majority countries on the explicit basis of Islam. There is little point in expanding on this point because it is a political calculation for states to determine which states to engage in the objecting process and for what reasons. ${ }^{55}$ So, to claim these are double standards, and thus

there is little reference to the way in which the question of reservations influence the issues at stake. This is indicative of the more general invisibility of the technical framework of treaty-making in debates about the substance of human rights norms and its universal appeal. The explicit defense of a form of universalism and even essentialism by Martha Nussbaum against relativistic accounts of women's dignity and gender equality does not systematically relate to the mediating role played by states in the formulation of global norms. See, e.g., Martha C. Nussbaum, Public Philosophy and International Feminism, 108 Етнісs 762, 792 (1998).

55 Brunei Darussalam joined CEDAW in 2006 with a reservation to Article 9(2) (equality with regard to inheritance of nationality), and otherwise expressing "its reservations regarding those provisions of the said Convention that may be contrary to the Constitution of Brunei Darussalam and to the beliefs and principles of Islam;" objections were filed by Austria, Belgium, Canada, the Czech Republic, Denmark, Estonia, Finland, France, Germany, Greece, Hungary, Ireland, Italy, Latvia, the Netherlands, Norway, Poland, Portugal, Romania, Slovakia, Spain, Sweden, and the United Kingdom.

Bahrain acceded in 2002 with reservations to Articles 9(2), 15(4) (freedom of movement) and 16 (equality in matters relating to marriage), and adding a reservation to Article 2 "in order to ensure its implementation within the bounds of the provisions of the Islamic Shariah;" objections were filed by Austria, Denmark, Finland, Germany, Greece, the Netherlands, Sweden, and the UK.

Mauritania joined in 2001, stating upon accession that it did "approve it in each and every one of its parts which are not contrary to Islamic Sharia [sic] and are in accordance with our Constitution;" objections were filed by Austria, Denmark, France, Finland, Germany, the Netherlands, Ireland, Norway, Portugal, Sweden, and the UK.

Oman reserved upon accession to CEDAW in 2006 Articles 9(2), 15(2) (equality in freedom of movement) and 16 and moreover reserved "[a]ll provisions of the Convention not in accordance with the provisions of 
an unfair or objectionable practice in itself misses the point. There have not been anywhere near the number of objections necessary to constitute an automatic legal consequence for the reserving states. That being said, the fact remains that objections made by states provide arguments for scholars, committees, and even judges to ultimately remark on the legal effects of the reservations.

Noting that there are patterns of state objections to reservations seems prudent given

the Islamic sharia [sic] and legislation in force in the Sultanate of Oman." Objections were filed by Austria, Belgium, Denmark, the Czech Republic, Finland, France, Germany, Greece, Hungary, Ireland, Italy, Latvia, the Netherlands, Poland, Portugal, Romania, Slovakia, Sweden, Spain, and the UK.

Qatar acceded in 2009 with a series of reservations: to Article 2 (because of constitutional rules relating to rules of succession), Article 9(2) (for being inconsistent with Qatari law), Article 15(1) (for being inconsistent with Islamic law on matters of inheritance and testimony), 16 (1) (for being inconsistent with Islamic law on a variety of issues); Qatar added also an interpretive declaration on Article 1 to the effect that "in accordance with the provisions of Islamic law and Qatari legislation, the phrase 'irrespective of their marital status' is not intended to encourage family relationships outside legitimate marriage," and an interpretive declaration on Article 5, to the effect that the modification of "patterns" referred to therein "must not be understood as encouraging women to abandon their role as mothers and their role in child-rearing, thereby undermining the structure of the family." Objections were lodged by Austria, Belgium, the Czech Republic, Estonia, Finland, Hungary, Ireland, Italy, Latvia, Mexico, the Netherlands, Norway, Poland, Portugal, Romania, Slovakia, Spain, Sweden, and the UK.

Saudi Arabia acceded in 2000, stating that "[i]n case of contradiction between any term of the Convention and the norms of Islamic law, the Kingdom is not under obligation to observe the contradictory terms of the Convention." Objections were filed by Austria, Denmark, Finland, France, Greece, Ireland, the Netherlands, Norway, Portugal, Spain, Sweden, and the UK.

Syria joined in 2003, and made reservations to Articles 9(2), 15 (4), 16 (1) and 16(2) (specifically for being "incompatible with the provisions of the Islamic Shariah" as well as (like many other States) Article 29 on settlement of disputes through arbitration; objections were filed by Austria, Denmark, Estonia, Finland, France, Germany, Greece, Italy, the Netherlands, Norway, Romania, Spain, Sweden, and the UK.

The United Arab Emirates acceded in 2004, with notable reservations to Articles 2 (which "violates the rules of inheritance established in accordance with the precepts of the Shariah"), 15(2) (which is "in conflict with the precepts of the Shariah regarding legal capacity, testimony and the right to conclude contracts"), and 16 (insofar as the provisions of the article are "in conflict with the principles of the Shariah"). Objections were filed by Austria, Denmark, Finland, France, Germany, Greece, the Netherlands, Norway, Poland, Portugal, Spain, Sweden, and the UK.

Convention on the Elimination of All Forms of Discrimination against Women, U.N. TREATY Collection, https://treaties.un.org/Pages/ViewDetails.aspx?src=TREATY\&mtdsg_no=IV-8\&chapter $=4 \&$ clang $=$ en [perma.cc/7G9R-R2YJ] (contains the complete text of the reservations and objections) [hereinafter Reservations]. 
the influence that the objections may ultimately have in a legal determination. Reservations to CEDAW are not treated uniformly, not even religiously motivated reservations to CEDAW. The Gulf States, which ratified CEDAW after 2000, triggered the most state objections to their reservations. This was the case despite the much more particular nature of their reservations, compared for instance to Egypt's or Bangladesh's reservations, which were formulated over twenty years earlier and have to this day garnered only a handful of objections. To take another example, Israel makes blanket reservations to CEDAW, arguably exempting personal status laws of religious communities from scrutiny, but has met no state objections. Meanwhile, the United Arab Emirates' reservations, which are quite specific, have no less than thirteen state objections. This pattern of reservations and objections evokes an opposition between Muslim-majority states and European states, in terms of singling out the former in the pattern of objections lodged by the latter.

\section{Islamic Reservations as a Legal Formula}

The wording of the so-called "Islamic reservations" is resonant with the Constitutions of many Muslim-majority countries, which mandate that religious law be a primary source of law. For example, the very broad reservation made by Egypt to CEDAW on Article 2 claims that Egypt is "willing to comply with the content of this article, provided that such compliance does not run counter to the Islamic Sharia [sic]." ${ }^{" 56}$ Article 2 of the Egyptian Constitution states: "Islam is the religion of the state, and the Arabic language is its official language. The principles of Islamic law are the chief source of legislation." ${ }^{57}$ The position of a reserving state such as Egypt is that a reservation referring to the normative supremacy of Shari'a is the only way to maintain some semblance of coherence between international commitments, on the one hand, and Islamic jurisprudence as a source of law on the other hand. The argument of some of the objecting states was, however, that the reservation to Article 2 is objectionable as it runs counter to the object and purpose of the treaty. ${ }^{58}$

Scholars and human rights organizations have picked up the position of the objecting states in the years since the initial ratifications of the treaty. The focus on women's rights in countries that have authored Shari'a based reservations has been diverted or to some

56 Comm. on the Elimination of Discrimination Against Women, Declarations, Reservations, Objections and Notifications of Withdrawal of Reservations Relating to the Convention on the Elimination of All Forms of Discrimination Against Women, U.N. Doc. CEDAW/SP/2006/2, at 12 (Apr. 10, 2006).

57 Constitutional Declaration of 2011 [Provisional Constitution of the Arab Republic of Egypt], Mar. 30, 2011, art. 2 (Egypt), http:/www.egypt.gov.eg/english/laws/constitution/default.aspx [perma.cc/3M9DMK6K].

58 Germany and Sweden took that position. See Reservations, supra note 55. 
degree dominated by the reservation issue, in the sense that many arguments focus not on concrete state action in practice, but on what is seen as the theoretically inevitable consequences of reservations. For example, a 2004 Human Rights Watch (HRW) report entitled Divorced from Justice, argued not only that the laws in Egypt as they were written at that time fell short of international obligations to promote equality between men and women, but that the reservation to Article 2 of CEDAW "goes against the very object and purpose of the Convention." The report adds that "[t]his reservation, if put into practice, inevitably results in discrimination against women on the basis of sex, which is contrary to the fundamental purpose of the Convention." ${ }^{\circ 9}$ The idea that this reservation inevitably results in discrimination means that very specific content is read into the reservation. An understanding of the reservation as a mere modification of the terms or a variation of the treaty is discarded and the reservation is instead interpreted as necessarily a limitation —or, worse, a total negation — of the terms of the treaty. Under this interpretation, the reservation cannot be understood as promoting non-discrimination within an Islamic framework, because within an Islamic framework non-discrimination on the basis of gender is interpreted as simply impossible. The HRW Report made a very compelling case for the real and serious problems with the divorce laws in Egypt. Sadly, by emphasizing the centrality of the Shari'a based reservation, they positioned themselves as upholding a necessary opposition between human rights law and Islamic law. As an apparent afterthought, the HRW Report then stated, "Human Rights Watch does not advocate for or against Shari'a per se, or any other system of religious belief or ideology; nor do we seek to judge or interpret the principles of any religion or faith. We are simply concerned about human rights violations resulting from the implementation of any legal system, in any country."

\section{The Sine Qua Non of Ratification}

Although condemnation of the Shari'a reservations is widespread, it is also generally well known that reserving states would not have accepted CEDAW had it not been for the reservations they made:

Preservation of religious laws and customs, in reality, may have been the sine qua non of ratification for these States. Submitting vaguely worded reservations enables State Parties to join CEDAW without specifying precisely what treaty commitments they are accepting. Such reservations,

59 Human Rights Watch, Divorced from Justice: Women's Unequal Access to Divorce in Egypt 9, 39 (Nov. 30, 2004).

$60 \quad I d$. 
accepted by the vast majority of State Parties without objection or comment, set a poor precedent and highlight the flaws inherent in CEDAW from the outset. ${ }^{61}$

In general terms, in the pursuit of universal ratification of the treaty the vast majority of states have allowed for broadly worded reservations to CEDAW. ${ }^{62}$ And, as far as the specific reservations are concerned, the tension between Muslim-majority states and European states over equality provisions in personal status laws did not materialize all of a sudden at the stage of ratification of CEDAW. Indeed, the way in which the actual Convention is worded reflects the tensions that existed during the drafting process, which prevented clarifications on key concepts. ${ }^{63}$ Yet, despite the opposition in the starting positions, some European objecting states now display what seems to be an attribution of bad faith to reserving Muslim-majority countries. This presumption of bad faith guides the way in which the debate has unfolded. It is an interesting point, which has been repeated even as countries such as Saudi Arabia have made changes in domestic legislation despite the reservations to CEDAW. It is perhaps notable that Saudi Arabia, with their twenty percent quota of seats reserved for women in parliament, is outpacing the International Law Commission in terms of female representation. ${ }^{64}$

Although several objections were initially made on the basis of the overly broad or vague nature of the reservations, as the reservations were made more specific over time the nature of the objections transformed. Egypt's reservation to Article 2 of CEDAW was particularly contentious, as it was - similarly to the reservation made by Malaysiaboth general and made contingent upon compatibility with Islamic Shari'a. ${ }^{65}$ Instead of

61 Michele Brandt \& Jeffrey L. Kaplan, The Tension Between Women's Rights and Religious Rights: Reservations to CEDAW by Egypt, Bangladesh and Tunisia, 12 J.L. \& ReLIGION 105, 141 (1995) (internal reference omitted).

62 Catherine J. Redgwell, Universality or Integrity? Some Reflections on Reservations to General Multilateral Treaties, 64 BRIT. Y. B. INT'L L. 245 (1994).

63 See, e.g., Marsha Freeman, Reservations to CEDAW: An Analysis for UNICEF (Dec. 2009), http://www. unicef.org/gender/files/Reservations_to_CEDAW-an_Analysis_for_UNICEF.pdf [perma.cc/7YMW-HCDY].

64 Proportion of seats held by women in national parliaments (\%), WoRLD BANK, http://data.worldbank. org/indicator/SG.GEN.PARL.ZS [perma.cc/DNW8-8YLD] (official statistics on Saudi Arabia from the World Bank IDA).

65 Malaysia's initial reservation, made upon accession in 1995, read:

The Government of Malaysia declares that Malaysia's accession is subject to the 
focusing on the specific kind and content of reservation being made, the position began to emerge that reservations to Article 2 were problematic because of the nature of Article 2 . Reservations made to Article 2 became more visibly contentious as many commentators subsequently argued that Article 2 had to be understood as the heart of the Convention itself, and so reservations should not be allowed on this Article as it sets forth the object and purpose of the treaty. ${ }^{66}$ In particular, the position emerged in the literature that Article 2 was the basis of the Convention because it prohibits sex discrimination and provides the logistical blueprint for combating it at the local level. Reserving states could have asked why, if reservations to this Article are legally impermissible, there was not an explicit prohibition on reservations to this article set out in the treaty itself. ${ }^{67}$ Only in 2010 did the CEDAW Committee establish, through the formulation of General Recommendation 28, that Article 2 did set out the object and purpose of the treaty. ${ }^{68}$ This helped solidify the

understanding that the provisions of the Convention do not conflict with the provisions of the Islamic Sharia' law and the Federal Constitution of Malaysia. With regards thereto, further, the Government of Malaysia does not consider itself bound by the provisions of articles 2 (f), 5 (a), 7 (b), 9 and 16 of the aforesaid Convention.

That reservation was objected to by Denmark. Subsequently the part of the reservation touching on Article 2 was withdrawn in 1997, and the rest of the reservation was further specified. The new reservation was in turn objected to by France and the Netherlands. See the text of the various communications to the U.N. Secretary General at Reservations, supra note 55, at n.27.

66 Clark, supra note 30, at 299 ("This writer concurs with the view taken by the objecting states, that Bangladesh's reservation to Article 2 is manifestly incompatible with the object and purpose of the Convention (which very object and purpose is set out in Article 2).").

67 At the time of negotiating the CEDAW, the notion that reservations to a provision deemed central to the whole purpose of a treaty could be prohibited was of course nothing extraordinary. Article 33 of the 1951 Refugee Convention, relating to the obligation of non-refoulement, was notoriously made immune from reservations by the 1967 Protocol on the Status of Refugees. See Protocol Relating to the Status of Refugees, Jan. 31, 1967, 606 U.N.T.S. 267 (entered into force Oct. 4, 1967). On Article 33 as embodying the object and purpose of the convention, see UNHCR, Advisory Opinion on the Extraterritorial Application of NonRefoulement Obligations under the 1951 Convention relating to the Status of Refugees and its 1967 Protocol, Jan. 26, 2007, http://www.unhcr.org/4d9486929.pdf [perma.cc/83CX-LU9K].

68 The issue follows the usual debate. If this is the object and purpose of the treaty, why then was there not a provision specifying that reservations could not be made to Article 2? General Recommendation 28 establishes Article 2 as the heart of the treaty:

Article 2 is crucial to the full implementation of the Convention, since it identifies the nature of the general legal obligations of States parties. The obligations enshrined in article 2 are inextricably linked with all other substantive provisions of the Convention, as States parties have the obligation to ensure that all the rights enshrined in the Convention are fully respected at the national level. 
position that reservations to Article 2, consequently primarily Islamic reservations, were contrary to the object and purpose of the treaty.

The legal effect of these reservations, however, remains open. Although the European response to the Islamic reservations in terms of filing objections has been systematic and has increased as new states have ratified over time, there is still a minority of states that have objected to these reservations. State objections have not had a direct legal impact on the filing of reservations, although they may have influence in preventing the emergence of alternative interpretations of the treaty and have indirect influence over future legal cases. ${ }^{69}$ In this context, the CEDAW Committee's treatment of reservations has been considered more aggressive than that of other human rights committees. With respect to the Islamic reservations in general, and the reservations to Article 2 in particular, the Committee has taken a particularly forceful approach. ${ }^{70}$ However, as will be shown, there is still room for

And the Committee adds:

The Committee considers article 2 to be the very essence of the obligations of States parties under the Convention. The Committee therefore considers reservations to article 2 or to subparagraphs of article 2 to be, in principle, incompatible with the object and purpose of the Convention and thus impermissible in accordance with article 28, paragraph 2.

Comm. on the Elimination of Discrimination against Women, General Recommendation No. 28 on the core obligations of States parties under article 2 of the Convention on the Elimination of All Forms of Discrimination against Women, at 2, 10, ๆศ 6, 41, U.N. Doc. CEDAW/C/GC/28 (Dec. 16, 2010) [hereinafter General Recommendation No. 28].

69 The position of key objecting states appears to be one intended to have such an indirect impact, by way of creating a systematic response. For an account of the transformation of the Nordic position in relation to norm-generating treaties, see generally Jan Klabbers, Accepting the Unacceptable? A New Nordic Approach to Reservations to Multilateral Treaties, 69 NORDIC J. InT'L L. 179 (2000).

70 In 1998, following the Human Rights Committee's adoption of General Comment No. 24 on reservations, supra note 31, the CEDAW Committee adopted a Statement on Reservations to the Convention on the Elimination of All Forms of Discrimination Against Women in which it outlines a general position. Rep. of the Comm. on the Elimination of Discrimination against Women, Eighteenth and Nineteenth Sessions, U.N. Doc. A/52/38/Rev.1, Part II, \ 1 [hereinafter Statement on Reservations]. In its first paragraphs, it lays out the problem of reservations, and of some reservations in particular, in broad terms:

Reservations affect the efficacy of the Convention, whose objective is to end discrimination against women and to achieve de jure and de facto equality for them. Reservations prevent the Committee from assessing the progress of States parties' implementation of the Convention, limit its mandate and potentially affect the entire human rights regime. Some States are concerned about a perceived conflict between article 2 and the Islamic shariah law. In other instances, States have entered reservations, which, although unspecific, are 
interpretation and debate regarding the legal effect of the Islamic reservations.

\section{The CEDAW Committee: General Recommendation No. 28}

In 2010, the CEDAW Committee issued General Recommendation No. 28 on the Core Obligations of States Parties under Article 2 of CEDAW..$^{71}$ This is a significant Recommendation in many respects. The CEDAW Committee attempts here to constrain states in a subtle, yet powerful, way by setting out the Committee's understanding of Article 2. That involves, among other things, establishing the impermissibility of reservations to Article $2^{72}$ and elaborating on what is considered central by the Committee to the functioning

broad enough to encompass article 2. These reservations pose an acute problem for the implementation of the Convention and for the Committee's ability to monitor compliance with it. Several have entered reservations to article 2 to protect rights of succession to the throne and to chiefly and other traditional titles. This too is discriminatory against women $\ldots$

When reservations are made to the Convention on the Elimination of All Forms of Discrimination against Women, there can be a double impact. By entering a reservation, the State indicates its unwillingness to comply with an accepted human rights norm. It also ensures that women's inequality with men will be entrenched at the national level. The promise given to its women when the State ratifies the Convention is not therefore fulfilled.

Id. at $48-49$, 1 ศ $10,15$.

71 General Recommendation No. 28, supra note 68.

$72 I d$. at 10,91 :

The Committee considers article 2 to be the very essence of the obligations of States parties under the Convention. The Committee therefore considers reservations to article 2 or to subparagraphs of article 2 to be, in principle, incompatible with the object and purpose of the Convention and thus impermissible in accordance with article 28, paragraph 2.

Similarly, in its Statement on Reservations, the Committee declares Articles 2 and 16 to be intimately related to, if not expressive of, the object and purpose of the CEDAW:

The Committee holds the view that article 2 is central to the objects and purpose of the Convention. States parties which ratify the Convention do so because they agree that discrimination against women in all its forms should be condemned and that the strategies set out in article 2, subparagraphs (a) to (g), should be implemented by States parties to eliminate it....

Neither traditional, religious or cultural practice nor incompatible domestic laws and policies can justify violations of the Convention. The Committee also remains convinced 
of what it sees as a "dynamic" Convention. ${ }^{73}$ Significantly, the Committee does not, however, state that reservations to Article 2 are invalid, even if they are impermissible. ${ }^{74}$ "Impermissibility" allows the Committee to continue to ask state parties for clarifications on the meaning of the reservations, while requesting that state parties remove the reservation voluntarily. ${ }^{75}$ Though the Committee engages the state regarding the permissibility of the

that reservations to article 16 , whether lodged for national, traditional, religious or cultural reasons, are incompatible with the Convention and therefore impermissible and should be reviewed and modified or withdrawn.

Statement on Reservations, supra note 70, at 49, $9 \uparrow 16-17$.

73 General Recommendation No. 28, supra note 68, at 1, ๆ 2:

The Convention is a dynamic instrument that accommodates the development of international law. Since its first session in 1982, the Committee on the Elimination of Discrimination against Women and other actors at the national and international levels have contributed to the clarification and understanding of the substantive content of the Convention's articles, the specific nature of discrimination against women and the various instruments required for combating such discrimination.

74 In this the CEDAW Committee follows the language used by the Human Rights Committee in General Comment No. 24, supra note 31, contra the European Court of Human Rights which inspired the Human Rights Committee to adopt its position on reservations in the first place. See, e.g., Belilos v. Switzerland, 132 Eur. CT. H.R. (ser. A), ๆ 60 (1987) ("[T] he declaration in question does not satisfy two of the requirements of Article 64 (art. 64) of the Convention, with the result that it must be held to be invalid."); see also Loizidou v. Turkey, 310 Eur. Cт. H.R. (ser. A.), 989 (1995) (preliminary objections) ("[T] he Court concludes that the restrictions ratione loci attached to Turkey's Article 25 and Article 46 (art. 25, art. 46) declarations are invalid.”).

75 As the General Recommendation itself mentions it, "States parties that have entered reservations to article 2 or to subparagraphs of article 2 should explain the practical effect of those reservations on the implementation of the Convention and should indicate the steps taken to keep the reservations under review, with the goal of withdrawing them as soon as possible." General Recommendation No. 28 , supra note 68 , $\uparrow 41$. It should be noted that the CEDAW Committee has adopted the language of invalidity in the context of elaborating on the meaning of Article 16:

Inequality in the family underlies all other aspects of discrimination against women and is often justified in the name of ideology, tradition and culture. An examination of States parties' reports reveals that in many States, the rights and responsibilities of married partners are governed by civil or common law principles; religious or customary laws and practices; or some combination of such laws and practices; that discriminate against women and do not comply with the principles set out in the Convention ....

Many of the States parties that maintain such legal arrangements have entered reservations to all or parts of articles 16 and 2. The Committee on the Elimination of Discrimination against Women has repeatedly noted with concern the extent of these reservations, which it considers invalid because they are incompatible with the object and purpose of the 
reservations, the Committee asserts that all obligations under the Convention remain in effect as treaty obligations irrespective of the reservations. It simultaneously asserts a substantive interpretation about the meaning of equality that is at the heart of the dispute between many Muslim-majority states and the Committee.

\section{General Comment 24}

General Recommendation 28 is an impressive document for its political ambition as well as skillful diplomacy and legal analysis. ${ }^{76}$ It is interesting to compare this to General

Convention.

Comm. on the Elimination of Discrimination against Women, General Recommendation 29 on article 16 of the Convention on the Elimination of All Forms of Discrimination against Women, Economic consequences of marriage, family relations and their dissolution, U.N. Doc. CEDAW/C/GC/29, at 3-4 (Feb. 26, 2015) [hereinafter General Comment No. 29].

The CEDAW Committee has refused so far to declare specific reservations invalid for the purpose of discarding them in the context of an individual communication, as famously done by the Human Rights Committee. In Rawle Kennedy v. Trinidad and Tobago, Decision on Admissibility, Commc'n No. 845, U.N. Doc. CCPR/C/67/D/845/1999 (Dec. 31, 1999) [hereinafter Kennedy v. Trinidad and Tobago (Admissibility)], the Human Rights Committee had disregarded the reservation filed by Trinidad and Tobago to the Optional Protocol to the International Covenant and Civil and Political Rights, and moved on to the merits, on the grounds that

The present reservation, which was entered after the publication of General Comment No. 24, does not purport to exclude the competence of the Committee under the Optional Protocol with regard to any specific provision of the Covenant, but rather to the entire Covenant for one particular group of complainants, namely prisoners under sentence of death. This does not, however, make it compatible with the object and purpose of the Optional Protocol. On the contrary, the Committee cannot accept a reservation which singles out a certain group of individuals for lesser procedural protection than that which is enjoyed by the rest of the population. In the view of the Committee, this constitutes a discrimination which runs counter to some of the basic principles embodied in the Covenant and its Protocols, and for this reason the reservation cannot be deemed compatible with the object and purpose of the Optional Protocol. The consequence is that the Committee is not precluded from considering the present communication under the Optional Protocol.

For the CEDAW Committee the point is still to encourage states to withdraw the reservations, based on the notion that such reservations are not only impermissible, but unnecessary. See id. at 51 . Where in 1998 the CEDAW Committee said "impermissible," it says now "invalid," and clarifies thereby that "validity" has a specific function related to the legal effect of the reservation, which the Committee has not yet examined in a concrete case.

76 This is of course the mandate of the CEDAW Committee: to uphold the Convention. See Committee 
Comment 24 from the Human Rights Committee, which set off an open conflict and controversy between state parties and the Committee. ${ }^{77}$ In it the Human Rights Committee argued that it had the competence to assess the validity and legal effects of reservations. As a result of the issuance of General Comment 24, the reports by International Law Commission's Special Rapporteur Alain Pellet directly addressed the issue of reservations to human rights treaties and the legal effects of reservations considered invalid by monitoring and adjudicating bodies. ${ }^{78}$ Although his appointment was to produce some solutions to the controversial topic, as indicated above, several issues that are touched off by the reservations issue remain ultimately unresolved as such, not the least of which being whether or not there is a schism between human rights law and regular international law, and one between the so-called universal international human rights law and regional human rights systems. ${ }^{79}$ At a lower level of abstraction, however, what I want to discuss

on the Elimination of Discrimination against Women: Mandate, U.N. Off. of the High Comm'R of Human Rights, http://www.ohchr.org/EN/HRBodies/CEDAW/Pages/Mandate.aspx [perma.cc/B7NP-EJN7] ("For the purpose of considering the progress made in the implementation of the present Convention [on the Elimination of All Forms of Discrimination against Women], there shall be established a Committee on the Elimination of Discrimination against Women.").

77 General Comment No. 24, supra note 31. See Human Rts. Comm., Observations by the United States on General Comment No. 24(52) on Issues Relating to Reservations Made upon Ratification or Accession to the Covenant or the Optional Protocol thereto, or in Relation to Declarations under Art. 41 of the Covenant, U.N. Doc. A/50/40 (Supp.), at 131 (Oct. 3, 1995). For an interesting account of General Comment 24 as a legal event, see generally Akbar Rasulov, The Life and Times of the Modern Law of Reservations: The Doctrinal Genealogy of General Comment No. 24, 14 Austrian Rev. Eur. \& Int'L. L. OnLine 103 (2009).

78 See Alain Pellet (Special Rapporteur), Second Report on Reservations to Treaties, U.N. Doc. A/CN.4/477 (June 13, 1996).

79 I am setting aside a detailed treatment of reservations in the European Court of Human Rights for the moment for the sake of time, but one should note again two important cases, Belilos v. Switzerland, 132 EuR. CT. H.R. (ser. A) (1987) and Loizidou v. Turkey, 310 Eur. CT. H.R. (ser. A.) (1995), which have set the basis for a strong position by the Court regarding the treatment of incompatible reservations. It allows in particular the Court to effectively sever invalid reservations to the European Convention while keeping the states parties to the conventions. The reasoning behind this is that the European Convention is a particular kind of treaty, which is distinct from general international human rights treaties. In the words of the European Court, regarding the permissibility of territorial reservations, which were the issue in this case:

If, as contended by the respondent Government, substantive or territorial restrictions were permissible under these provisions, Contracting Parties would be free to subscribe to separate regimes of enforcement of Convention obligations depending on the scope of their acceptances. Such a system, which would enable States to qualify their consent under the optional clauses, would not only seriously weaken the role of the Commission and Court in the discharge of their functions but would also diminish the effectiveness of the Convention as a constitutional instrument of European public order (ordre public). 
here is the specific treatment of the invalidity or, more precisely, the impermissibility of "Shari'a reservations" from the point of view of the specificity of human rights treaties in general, or CEDAW in particular.

Alain Pellet claimed that the controversy between some states and the Human Rights Committee resulted from the combination of various factors. First, the issue as presented in General Comment 24 arises as an issue for human rights treaties, since the monitoring "treaty bodies," such as the Human Rights Committee or the CEDAW Committee, were created specifically to oversee state compliance with human rights conventions, as part of an institutional relationship that was not originally envisioned when the Vienna Convention of the Law of Treaties 1969 was created. Subsequently, the treaty bodies in general, and the Human Rights Committee in particular, have taken a broad view of their own powers. Against this backdrop, the Human Rights Committee asserted in its General Comment 24 its competence to judge the validity of a reservation, and to attach a specific legal remedy, that is, that the invalid reservation would be severed from the treaty and the reserving state would be bound by the treaty in its entirety, including the article targeted by the reservation. ${ }^{80}$ This is the main reason for the opposition between some state parties and the Human Rights Committee, an opposition that Alain Pellet describes as contentious and even violent:

[T] he human rights treaty bodies have held to a particularly broad concept of their powers in this field: not only have they recognized their own competence to assess the compatibility of a reservation with the object and purpose of the treaty that established them, but they have also seemed to consider that they had a decision-making power to that end, even when they are not otherwise so empowered and, applying the "severability" theory, they have declared that the States making the reservations they have

Loizidou, 310 Eur. CT. H.R. (ser. A.), 75 (1995). See also Korkelia, supra note 40, at 442-44.

General Comment No. 24, supra note 31, at 918 :

It necessarily falls to the Committee to determine whether a specific reservation is compatible with the object and purpose of the Covenant.... Because of the special character of a human rights treaty, the compatibility of a reservation with the object and purpose of the Covenant must be established objectively, by reference to legal principles, and the Committee is particularly well placed to perform this task. The normal consequence of an unacceptable reservation is not that the Covenant will not be in effect at all for a reserving party. Rather, such a reservation will generally be severable, in the sense that the Covenant will be operative for the reserving party without benefit of the reservation. 
judged to be invalid are bound by the treaty, including by the provision or provisions of the treaty to which the reservations applied;

In so doing, they have aroused the opposition of States, which have no interest in being bound by a treaty beyond the limits which they accept, which they expect to be able to interpret as freely as possible; some States have reacted particularly violently and gone so far as to deny that the bodies in question have any jurisdiction in the matter[.]

This is compounded by the hypersensitivity of human rights activists and human-rights doctrine in this area, which has done nothing to calm a contentious debate that is nevertheless largely artificial. ... Furthermore, the human rights treaty bodies have held to a particularly broad concept of their powers in this field: not only have they recognized their own competence to assess the compatibility of a reservation with the object and purpose of the treaty that established them, but they have also seemed to consider that they had a decision-making power to that end, even when they are not otherwise so empowered.$^{81}$

Pellet wrote this five years before the CEDAW Committee issued General Recommendation 28, which is no less ambitious than General Comment 24, but has received significantly less press coverage following its issuance. Perhaps part of the reason is that the CEDAW Committee did not assert here its competence to "rule" on the legal effect of the reservation, even though the Committee views this competence as within their power, as indicated by the fact that it simply stated that reservations to Article 2 are a priori "impermissible," and subsequently declared reservations to Article 16 to be "invalid." 82 The idea is to state the Committee's view or opinion with a view not to take operational action, but rather to invite states to draw the appropriate consequences by withdrawing

81 Alain Pellet (Special Rapporteur on Reservations to Treaties), Tenth report on reservations to treaties, at 178, 154, U.N. Doc. A/CN.4/558 (2005). This refers in particular to General Comment No. 24, supra note 31, If 18 (in which the Human Rights Committee states that "[i]t necessarily falls to the Committee to determine whether a specific reservation is compatible with the object and purpose of the Covenant" and proceeds to take position in favor of the severability of reservations from the State's consent to be bound by ratification or accession).

82 General Comment No. 29, supra note 75, 151 ("The Committee on the Elimination of Discrimination against Women has repeatedly noted with concern the extent of these reservations, which it considers invalid because they are incompatible with the object and purpose of the Convention."). 
the reservation. ${ }^{83}$ The state should voluntarily withdraw the reservations according to the CEDAW Committee. This approach has led the Committee to state that the reservations to Article 2, which it deems to express otherwise the object and purpose of the treaty, are incompatible, but not that they are expressly invalid. It has also led the Committee to say that it "considers" reservations to Article 16 invalid, and that they should therefore be withdrawn; the Human Rights Committee, on the other hand, stated very clearly that its opinion on invalidity of reservations was more a statement of fact than an opinion, and the contested reservation would become inoperative. ${ }^{84}$ When set against the stance of the Human Rights Committee, the CEDAW Committee is thus departing in appearance from the traditional understanding of Article 19(c) of the Vienna Convention, especially if one considers that the only alternative in handling reservations is dismissing them and leaving states to deal with the problem. However, noting that the CEDAW Committee had taken a "stronger position" on reservations than other human rights committees, the report of the Inter-Committee Working Group on reservations - that is, a committee where members of all human rights monitoring bodies meet to discuss the issue of reservations - contains the

83 For references to the difference in language and perspective between the Human Rights Committee and the CEDAW committee, see supra note 75.

84 See Kennedy v. Trinidad and Tobago (Admissibility), supra note 75. While deciding on the merits, the Human Rights Committee clarified further its approach in this case: "It decided that the reservation could not be deemed compatible with the object and purpose of the Optional Protocol, and that accordingly the Committee was not precluded from considering the communication under the Optional Protocol." Id. It is worth noting that even for the Committee members who dissented in the Kennedy communication - and wanted to offer a softer version of the Committee's General Comment No. 24 guidelines on admissibility of reservations - it is clear that the Committee has authority to decide, based on an interpretation of state consent, what should happen to the reservation and the Covenant for the reserving state:

It is not our intention within the framework of the present case to reopen the whole issue dealt with in General Comment No. 24. Suffice it to say that even in dealing with reservations to the Covenant itself the Committee did not take the view that in every case an unacceptable reservation will fall aside, leaving the reserving state to become a party to the Covenant without benefit of the reservation. As can be seen from the section of General Comment No. 24 quoted above, the Committee merely stated that this would normally be the case. The normal assumption will be that the ratification or accession is not dependent on the acceptability of the reservation and that the unacceptability of the reservation will not vitiate the reserving state's agreement to be a party to the Covenant. However, this assumption cannot apply when it is abundantly clear that the reserving state's agreement to becoming a party to the Covenant is dependent on the acceptability of the reservation. The same applies with reservations to the Optional Protocol.

Id. at 270, $\uparrow 16$ (Individual opinion (dissenting) by Nisuke Ando, P.N. Bhagwati, Eckart Klein, and David Kretzmer). 
following observation:

Mr. Cees Flinterman [a member of the CEDAW committee] emphasized that even where a reservation was declared incompatible by the Committee, the dialogue with the reserving State was maintained. In some cases, the reservation that was declared incompatible has been withdrawn. An important distinction was made between a reservation being declared incompatible and being declared invalid. The Committee had been cautious not to declare a reservation to be invalid. Members of the working group agreed that it would be unwise for treaty bodies to do so, unless necessary. ${ }^{85}$

The Committee consciously benefits from the openness of the legal consequences of reservations that are considered by the Committee as incompatible with the object and purpose of the treaty. In this way the Committee seems to manage the ambivalence of the self-prescribed goals of universality and integrity of the treaty despite the existence of underlying fundamental disagreement. This may make sense for good realists, especially given the early experience of the Human Rights Committee, which faced considerable hostility due to its principled stance. But the CEDAW Committee's position is, strictly speaking, legally problematic. Not only does incompatibility not lead automatically to invalidity, but at least in the human rights context, it does not lead to any legal consequences at all, explicitly out of political or diplomatic considerations. Legal effect is generated by an objection to a reservation under the Vienna Convention. ${ }^{86}$ And the Human Rights Committee suggested that we apply a centralized mechanism for objections in the hand of the Committee, based on a declaration of invalidity. CEDAW's alternative is not an alternative.

\section{Eliminating Equity}

Given that the controversy surrounding reservations in CEDAW revolves around the proper universal understanding of equality, another aspect of this document must be noted. The concept of equality, left relatively bare in the treaty, ${ }^{87}$ is given some content, which

85 Rep. of the Meeting of the Working Group on Reservations, supra note 47 व 14.

86 See, e.g., Alain Pellet \& Daniel Muller, Reservations to Treaties: An Objection to a Reservation is Definitely not an Acceptance, in The Law of Treaties Beyond the Vienna Convention 37 (Enzo Cannizzaro ed., 2011).

87 As far as State obligations are concerned, the Convention prescribes a notion of equality that is mainly 
means that the Committee sets forth a definition of equality that must be adhered to by state parties. When the Committee indicates that some reservations to Article 2 are incompatible with the object and purpose of the treaty, this is what it means. General Recommendation No. 28 states the following regarding the meaning of equality between men and women:

Inherent to the principle of equality between men and women, or gender equality, is the concept that all human beings, regardless of sex, are free to develop their personal abilities, pursue their professional careers and make choices without the limitations set by stereotypes, rigid gender roles and prejudices. States parties are called upon to use exclusively the concepts of equality of women and men or gender equality and not to use the concept of gender equity in implementing their obligations under the Convention. The latter concept is used in some jurisdictions to refer to fair treatment of women and men, according to their respective needs. This may include equal treatment, or treatment that is different, but considered equivalent in terms of rights, benefits, obligations and opportunities. 88

The interpretation of Article 2 by the CEDAW Committee is broad and has allowed for flexibility depending on the rights at stake. ${ }^{89}$ But what remains clear is that in this General Recommendation, the Committee eliminates from within the interpretation of equality an admittedly contentious concept even within the Islamic tradition, that of gender equity. ${ }^{90}$ This exclusion generalizes a position of principle recurrent in the Committee's monitoring practice, namely, that 'the terms 'equity' and 'equality' are not synonymous

synonymous with a prohibition of discrimination based on gender. In other words, equality means enjoyment of fundamental rights by women in the same terms as enjoyment of fundamental rights by men. Article 3 says: "States Parties shall take in all fields, in particular in the political, social, economic and cultural fields, all appropriate measures, including legislation, to ensure the full development and advancement of women, for the purpose of guaranteeing them the exercise and enjoyment of human rights and fundamental freedoms on a basis of equality with men." CEDAW, supra note 1, at art. 3 .

88 See General Recommendation No. 28, supra note 68, at 5, ๆ 22 (emphasis added).

89 See, e.g., Simone Cusack \& Lisa Pusey, CEDAW and the Rights to Non-Discrimination and Equality, 14 Melbourne J. Int'L L. 54 (2013).

90 For an attempt at contrasting general conceptions of equality/equity in Islam and in the "West," see Elizabeth W. Fernea, Family Feminism or Individual Feminism? Different Histories, Different Paths to Gender Equity, 1 Hawwa 131 (2003). For a rejection of equity within the framework of Article 2 of CEDAW, see, e.g., Alda Facio \& Martha Morgan, Equity or Equality for Women? Understanding CEDAW's Equality Principles, 60 Ala. L. Rev. 1133 (2009). 
or interchangeable and can lead to conceptual confusion." ${ }^{.91}$ As already stated by the Committee, "[t]he Convention is directed towards eliminating discrimination against women and ensuring de jure and de facto (formal and substantive) equality between women and men," so that, as a result, states have been directed by the Committee to abandon the use of the term equity. ${ }^{92}$ To allow or not allow for equal but different rights and obligations in the family has been arguably the main source of the tension and conflict over Article 2. This Recommendation from the Committee settles this question through interpretative fiat, as it makes clear that the distinction between equality and equity is built into its own interpretation of the Convention and forms the object and purpose of the Convention.

It should be observed that the Committee eliminates as well an important strand of thought in broader feminist theory, closing an otherwise still open debate in academia. Cultural or difference feminism is in particular interpreted out of the realm of possibilities in the field of law..$^{93}$ Although it may not generally be considered a particularly popular

91 Comm. on the Elimination of Discrimination Against Women, Concluding Observations: Guyana, U.N. Doc. CEDAW/C/GUY/CO/3-6, ๆ 20 (July 22, 2005).

$92 I d$.

93 Even if one remains strictly within the Western canon, the exclusion is not insignificant, given the distinctive character of difference feminisms and their role in the unfolding of historical feminist debates. Difference feminism refers to a direction in feminism that seeks to articulate, defend, explore, or recover a particular epistemological, moral, psychological, or otherwise existential positioning associated with being a woman. See, e.g., Susan Moller Okin, Sexual Difference, Feminism, and the Law, 16 L. \& Soc. Inquiry 553 (1991). In some cases, the project has included the assertion and demonstration of women's point of view as qualitatively superior to that of men, as a reversal of socially contingent patriarchy. In all cases, difference feminism does not start with the postulate of equality, but as it name conveys, distinction, complementarity, or opposition. Under that umbrella, cultural feminism, generally associated with the work of Carol Gilligan, and in particular In a Different Voice: Psychological Theory and Women's Development (1982), is read as a movement favoring the flourishing of a women's culture based on their shared experience, traits, and given condition. Cultural feminism, as linked to second wave feminism, has been the object of consistent, and at times virulent, debates within feminist scholarship and social movements. See, e.g., Alice Echols, Cultural Feminism: Feminist Capitalism and the Anti-Pornography Movement, 7 Soc. Text 34 (1983); Verta Taylor \& Leila J. Rupp, Women's Culture and Lesbian Feminist Activism: A Reconsideration of Cultural Feminism, 19 Signs 32 (1993). In the genealogy of feminist movements, cultural feminism is usually contrasted with radical feminism, or dominance/domination feminism, represented most notoriously by Catharine M. MacKinnon. See CATHARINE M. MacKinnon, Feminism Unmodified: Discourses on Life and LaW 38-40 (1987) (distinguishing her project from that laid out by Gilligan, which she understands as seeking to restore value to the contribution of women under conditions of domination). See also Ellen C. Dubois et al., Feminist Discourse, Moral Values, and the Law - A Conversation, 34 Buff. L. Rev. 11, at 74 (1985) (questioning the "infuriating" lack of explanatory direction in Gilligan's depiction of a stated common position of women, as well as the association of women's identity (as "women") with stereotypically patriarchal notions of "the feminine."). On the differences between cultural and radical feminisms regarding conceptions of "woman" and "women's perspectives," see generally 
strand within progressive feminist circles, it is interesting that the Committee has declared the death of this strand of feminism internationally as a matter of fact. Likewise, for Islamic feminists who embrace the concept of gender equity, or at the very least the existence of a limited number of different rights and obligations for men and women within the family, the international debate has been closed. ${ }^{94}$ The Committee's position asserts that "difference feminism" and equality are per se incompatible.

Interestingly, in the CEDAW debate over the reservations based on Shari'a in the 1980s, Belinda Clark noted that the French delegation had stated that it did not perceive the reservations made by Islamic states as being incompatible with the object and purpose of the treaty. ${ }^{95}$ It may be safe to assume that this is not because the government of France had any particular affinity for Islam at that time, but rather perhaps because the concept of equity is not far from some lines of thought in the psychoanalytic French feminist tradition that emphasizes substantive equality over formal equality or, even more controversially, a strand which may precisely defend difference feminism. ${ }^{96}$

Within some schools of postmodern feminism and queer theory, the issue of the form equality must take is in any event still contested, or perhaps better stated, is always to be

Robin West, Jurisprudence and Gender, 55 U. CHI. L. Rev. 1 (1988). The distinction is contested by some who reject both currents. See Janet Halley, Sexuality Harassment, in Left Legalism/Left Critique 80, 87 (Wendy Brown \& Janet Halley eds., 2002). Forms of cultural feminism or "care" feminism have found a place more recently in debates within ecofeminism. See, e.g., Josephine Donovan, Animal Rights and Feminist Theory, 15 Signs 350 (1990); Josephine Donovan, Feminism and the Treatment of Animals: From Care to Dialogue, 31 Signs 305 (2006).

94 For a short account of equity and complementarity from within Islamic law and the Islamic tradition, see, e.g., Jane I. Smith, Women in Islam: Equity, Equality, and the Search for the Natural Order, 47 J. Aм. ACAD. ReLIG. 517 (1979).

95 Clark, supra note 30, at 285 ("France simply stated that it did not consider any of the reservations made to be incompatible with the object and purpose of the Convention."). Later, after 2000, France began objecting to reservations made by Islamic states based on Sharia. However, France later withdrew its reservations. See Comm. on the Elimination of Discrimination against Women, Consideration of Reports Submitted by States Parties Under Article 18, Combined Seventh and Eighth Periodic Reports of States Parties due in 2013: France, U.N. Doc. CEDAW/C/FRA/7-8, at 6 (Mar. 20, 2014).

96 See generally Luce Irigaray, Je, Tu, Nous (1990). This is especially true within the psychoanalytic tradition. "In any case, our need first and foremost is for a right to human dignity for everyone. That means we need laws that valorize difference. Not all subjects are the same, nor equal, and it wouldn't be right for them to be so. That's particularly true for the sexes. Therefore, it's important to understand and modify the instruments of society and culture that regulate subjective and objective rights." $I d$. at 14. 
contested..$^{97}$ And among feminists globally, and within the various schools of thought that form the global feminist movement, there is of course no consensus on the particular form equality must take as equality is always contextually dependent. ${ }^{98}$ Nor more prosaically is there a state in Europe, or elsewhere, that has managed to implement state policies that have worked to solve the difficult problem of securing absolute formal and substantive equality for women as they define it themselves. Women still earn at least fifteen percent less than their male counterparts for the same work, even in Nordic countries. ${ }^{99}$ And over a women's reproductive lifetime the wage gap in countries like Finland jumps to over twenty percent. ${ }^{100}$ Women still do the majority of unremunerated work at home, even in Finland. ${ }^{101}$ Reproductive differences and the asymmetrical work involved in childcare between men and women in heterosexual households continue to contribute to the problem for achieving

97 See, e.g., the work of Brenda Cossman. Brenda Cossman, A Matter of Difference: Domestic Contracts and Gender Equality, 28 Osgoode Hall L.J. 303 (1990); Brenda Cossman, Gender Performance, Sexual Subjects and International Law, 15 CANADIAN J.L. \& JuRIs. 281 (2002); Brenda Cossman, Feminism after the Critique of Feminism, 23 Adel. L. Rev. 389 (2002); Brenda Cossman, Turning the Gaze Back on Itself: Comparative Law, Feminist Legal Studies, and the Postcolonial Project, 1997 Utah L. Rev. 525 (1997).

98 Engaging with Third World feminism, though the issue of equality as such does not appear, Vasuki Nesiah maps out a few lines of thought in which Third World feminism is invested in reimagining the ways in which women's oppression in the Third World is constructed by dominant discourses. Underlying this is a project of complicating and multiplying the ways in which men and women's relationships can be variously understood. See Vasuki Nesiah, The Ground Beneath Her Feet: "Third World" Feminisms, 4 J. Int'L Women's Stud. 30 (2003).

99 Comm. on the Elimination of Discrimination Against Women, Concluding Observations: Finland, U.N. Doc. CEDAW/C/FIN/CO/7, at 8, 26 (Mar. 10, 2014). The gap has closed since the last report in 2008 in which the pay gap was twenty percent. See Comm. on the Elimination of Discrimination Against Women, Concluding Observations: Finland, U.N. Doc. CEDAW/C/FIN/CO/6, at 5, ๆ 25 (July 15, 2008).

100 Even for women in countries like Finland, the pay gap increases sharply at the ages when most women in Finland are raising children, moving up to $11 \%$ for 25-34 year olds and again jumping to $18.6 \%$ for $35-44$ year olds. The gap levels off at $19.9 \%$ for the next age grouping of $45-54$ year olds and peaks at $23 \%$ when women enter retirement. It is not possible to say conclusively from the statistics the pay gap results directly from having and raising children. However, women in their forties at the age of raising families, when they are also considered to be at their professional peaks, are earning almost $20 \%$ less than men. This is startling when considering that women in their early twenties in Finland begin their careers almost on par with men with only a 3.4\% pay gap. Gender Pay Gap Statistics, Eurostat: Statistics Explained, http://ec.europa.eu/ eurostat/statistics-explained/index.php/Gender_pay_gap_statistics (last visited Apr. 20, 2017) [perma.cc/ CQ7R-UYLH].

101 See, e.g., 4 Organization for Economic Cooperation and Development, Babies and BossesReCONCILING Work AND FAmily Life 200 (2005) (indicating that the ration of unpaid to paid labor is twice as high for women working full-time than for men in both Sweden and Finland). 
economic and social equality between men and women. ${ }^{102}$ Formal and substantive equality may be themselves sometimes in conflict as formal equality can lead to an increase in substantive inequality. And even when equality in a couple is achieved, it is often at the expense of economically disadvantaged women or older women. ${ }^{103}$ There are theoretical divisions on the best way to deal personally, and as societies, with the issues of gender difference and the family. Yet the human rights discourse takes the family as the "natural unit of society" without settling what kind of family that should be. ${ }^{104}$ This position is maintained despite the impact different variables in the form the family takes would have on questions of equality. The particular form the family takes is of course part of the problem to which feminist theory in its various forms has paid particular attention, and for which there is no consensus in theory or in state policy. The normativity of the family, be it heteronormativity, repronormativity, or even the norm that the family is the natural unit in society, is not uncontested, yet these differences are not acknowledged, nor are they neutral. ${ }^{105}$

Although the divisions on this issue have not been bridged within feminist thought, through the technical debate on reservations they are being stabilized as the one dominant, acceptable position within law. I would argue that in this case, it is accurate to apply what Boaventura De Sousa Santos calls "epistemicide,"106 or what Robert Cover more simply refers to as violence through juridical force. ${ }^{107}$ The Committee, in its collective desire to ground gender equality, is eliminating various positions within the equality debate. Equality means only one thing for the Committee, however flexible that vision may be, and as the next section shows, this one version of equality is predicated on the assumption

102 See especially Concluding Observations: Finland, supra note 99, at 8, \ 27.

103 Equality cannot be measured only on the basis of the respective positions of two people in a couple, but must be assessed with reference to all relevant members who contribute to the care of the home. When domestic labor is outsourced, the labor conditions of the people taking on the care must be taken into account. Equality is not achieved if it is on the backs of migrant women, disadvantaged women. The number of families who rely on the unpaid labor of female family members, grandmothers, aunts, sisters is certainly high globally. See, e.g., Gilbert G. Gonzalez, Labor Versus Empire: Race, Gender, Migration 221 (2004).

104 The United Nations has asserted this from the early years of the Universal Declaration of Human Rights. G.A. Res. 217 (III) A, Universal Declaration of Human Rights, art. 16, \3 (Dec. 10, 1948), http://www.ohchr. org/EN/UDHR/Documents/UDHR_Translations/eng.pdf [perma.cc/4YHY-PX2Y].

105 Katherine M. Franke, Theorizing Yes: An Essay on Feminism, Law, and Desire, 101 Colum. L. Rev. 181 (2001).

106 SAntos, supra note 20, at xix.

107 See generally Robert Cover, Violence and the Word, 95 Y ALE L.J. 1601 (1986). 
that specific economic and political structures are in place. These structures, in fact, do not exist globally, and, even among developed nations, they are facing challenges, if they exist at all. The elimination of different conceptions of equality relies, despite much debate and commitment over the past decades, on the public/private binary, which brings state-based practices under a higher level of scrutiny. In the following section I will argue that the opposition is created in part because many of the background assumptions about women's agency and how that agency gets assembled differently, depends in part on whether or not that woman is located in the global North or South and whether religion is publicly or privately organized.

\section{Bright Lines: Religion and the Public/Private Distinction in the CEDAW Committee}

Within the field of international law, groundbreaking arguments by Hilary Charlesworth, Christine Chinkin, and Shelley Wright established a feminist agenda for several decades and transformed the field of international law. ${ }^{108}$ It remains unclear at this point how much of this feminist critique has been absorbed by mainstream international law and how much has either been missed, distorted, co-opted or simply discarded. ${ }^{109}$ One crucial theoretical insight of feminist legal theory has been to reveal the public/private distinction in international law and how it structures gender oppression. ${ }^{110}$ Certainly the

108 Hilary Charlesworth et al., Feminist Approaches to International Law, 85 AM. J. INT'L L. 613, 625-34, 638-43 (1991). Hilary Charlesworth again set out a feminist agenda by providing a map and analysis of feminist methods. See Hilary Charlesworth, Feminist Methods in International Law, 93 Am. J. InT'L L. 379 (1999).

109 That was in fact a central question in Hilary Charlesworth, Not Waving but Drowning: Gender Mainstreaming and Human Rights in the United Nations, supra note 8. On the resistance of "general international law" to feminist insights and critique, see, e.g., Aaron Xavier Fellmeth, Feminism and International Law: Theory, Methodology, and Substantive Reform, 22 Hum. RTs. Q. 658 (2000). See also Fernando Tesón, Feminism and International Law: A Reply, 33 VIR. J. InT'L L. 647 (1993). In the same vein, see Anthony D'Amato, Book Review: Rebecca Cook (ed.), Human Rights of Women: National and International Perspectives, 89 Am. J. InT'L L. 840 (1995), followed by Hilary Charlesworth, Cries and Whispers: Responses to Feminist Scholarship in International Law, 65 Nordic J. InT'L L. 557 (1996). See also Anne Orford, Feminism, Imperialism and the Mission of International Law, 71 Nordic J. INT'L L. 275 (2002); José E. Alvarez, Book Review: Charlesworth, Hilary and Christine, Chinkin. The Boundaries of international Law: A Feminist Analysis, 95 Am. J. INT’L L. 459 (2001).

110 See Hilary Charlesworth, The Public/Private Distinction and the Right to Development in International Law, 12 Austl. Y. B. Int'L L. 190 (1988). See also Celina Romany, Women as Aliens: A Feminist Critique of the Public/Private Distinction in International Human Rights Law, 6 Harv. Hum. RTs. J. 87 (1993). For an account within a national context, see, e.g., Frances Olsen, The Family and the Market: A Study of Ideology and Legal Reform, 96 HaRv. L. R. 1497 (1983). 
reconceptualization of jus cogens norms to cover gender violence has been a coup, which relied on revealing how a public/private distinction systematically ignored violence against women. ${ }^{111}$

Against this feminist legacy, it is therefore interesting to see how mainstream arguments on women's rights can continue to function on the basis of public/private distinctions in law. The argument here is that, as a result of the biases of Liberal women's rights discourse, much of the debate over "Islamic reservations" to CEDAW relies in part on a persistent distinction between public and private religion, with pernicious consequences. There are two ways in which the CEDAW Committee has fallen victim to the reliance on a public/ private distinction as a relevant foundation for their work. First, the Committee makes the case that religion should cease to be so public, thereby pushing the kind of public discrimination that it condemns into the private sphere. Second, despite conscious efforts to the contrary, the Committee focuses attention and stronger language on formal inequalities based on religious doctrine, while leaving many substantive inequalities produced in secular contexts under-addressed. It may be a question of sequencing or of visibility, but there seems to be a difference in the way in which the reservations flag inequalities in Muslim-majority states and not inequalities in secular, European states as an example.

One caveat regarding the analysis needs to be made. It is not always possible to attribute a single position to the CEDAW Committee. In the absence of a general recommendation, what is available from the CEDAW Committee has consisted in discussions between representatives. Any pure argumentative or ideological line is therefore ephemeral, if existing at all, and so tendencies or lines are drawn out rather than coalescing into a singular absolute position. What seems to happen in fact inside the Committee is a recurrence of the reservations debate between the Committee and States Parties. Sadly, the reports from the Committee no longer include the full dialogue from the different experts as having individual voices. This practice has been replaced with a single voice from the Committee. But the positions from the state representatives and the Committee are in fact often no more different than the voices with the Committee itself. This is not surprising when one considers, for example, that among the past chairpersons of the CEDAW Committee, at least two have been Egyptian women who have at other times represented Egypt before the Committee. In the consideration of Egypt's report to the Committee in 2001, Ms. Mervat Tallawy, an Egyptian diplomat and former Chairperson of the CEDAW Committee, presented Egypt's report. She stated that after a national study, the findings were that there was no contradiction between Islamic Shari'a and the CEDAW, and that the reservation

111 Hilary Charlesworth \& Christine Chinkin, The Gender of Jus Cogens, 15 Hum. RTs Q. 63 (1993). 
to Article 2 was purely precautionary and should be removed due to the findings of the report. ${ }^{112}$ The expert from Tunisia, Ms. Aouij, was emphatically in favor of Egypt's approach to fulfill its treaty obligations within the scope of Islamic law saying,

[T] hat Egypt had showed a clear political will to promote the advancement of women and ensure that their rights were protected as full fledged citizens on an equal footing with men. In that regard, she hailed Law No. 1 for 2000 because its main beneficiaries were women. Its most outstanding, innovative feature was the granting to women of the unilateral right to divorce by repudiation, "khul." That form of divorce was based on the Islamic sharia. It had taken 10 years of negotiations and centuries of fierce resistance by men to secure a right, which could have been deduced from a wise and dynamic reading of the religious texts.

However, in the considerations, Ms. Ivanka Corti, an Italian national and also a former Chairperson of the CEDAW Committee, stated that it was time to withdraw the reservations to the treaty. Further, "[s]he disagreed with the delegation that religion provided for women's equality. It was one of the main reasons why women were in a position of inferiority."113 Likewise, another former Chairperson, and a Turkish national, Ms. Acar, also urged for the immediate withdrawal of the reservations, while stating, as it is reported, that "what happened in Egypt was also important for women throughout the Islamic world." "114 In that regard, she suggested that measures and policies aimed at eliminating discrimination against women also needed to be more clearly and openly related to the concept of universal norms of women's rights. Since improvement should be measured against universal norms and conditions, "it was very important for Egypt to withdraw its reservations ...." ${ }^{115}$ Egypt has not removed the reservation to Article 2, and though purely speculative, this may not be a result of the positions of those unsympathetic to the goals of CEDAW, but because of the disagreement over the proper role of religion in relation to women's rights.

112 Comm. on the Elimination of Discrimination against Women, Summary record of the 492nd meeting, U.N. Doc. CEDAW/C/SR.492, at 2, \ 8 (Mar. 26, 2001).

113 Id. at 5 , ๆ $24-25$.

$114 I$ Id. at $6, \uparrow 30$.

$115 I d$. 


\section{A. Public and Private Religion}

\section{The Committee and the Reservations}

From the previous section, it follows that the "Islamic reservations" to CEDAW are problematic not only because they support different privileges and obligations for men and women in the family, but primarily because they are asserted by the state emanating from a religious source. ${ }^{116}$ This is a slightly different debate than one over secularism, or it is at least a different way to think about the imposition of secularism as foundational for international human rights.

If we try to clarify its position, the CEDAW Committee's general line is one of ambivalence and suspicion towards "Islamic reservations." It does not say outright that the reference to Shari'a is forbidden, but seems ultimately to question the purpose for the State to subject performance of treaty duties to compliance with Shari'a. The generality of the reference is not problematic, contrary to what the ILC seems to think, because of the reservation's vagueness, but because the general formulation suggests that there is a possibility that Article 2 is not fully in line with the Shari'a. ${ }^{117}$ And the state is not allowed to endorse such a general contradiction. The most direct, but marginal, expression of this consists in linking religion to patriarchy, and thus to a structural conflict with CEDAW; ${ }^{118}$

116 Anne-Marie Slaughter reignited a debate in 2009 over the de facto reality that women in developed nations still bear the primary responsibility for raising children and this necessarily impacts women's work and women's equality. She subsequently argued that motherhood, and women's role in the family is the real issue for women's equality. Why Women Still Can't Have it All, Atlantic, June 20, 2012, at 84. The problem has no easy answers, and the question of women's advancement in the workplace in the U.S. tends to get framed as women's preferences. They are preferences to have children and preferences as to how involved in they are in the raising of the children.

117 A good example is provided by the line of questioning in the examination of Libya's initial report to the CEDAW Committee:

[Ms. Schöpp-Schilling] requested clarification of several points. Concerning article 16 of the Convention, she would like to know the relationship between the Sharia and the Convention, particularly in areas where their provisions were not identical. She saw a contradiction in stating that stereotypes on the roles of men and women had been eliminated from textbooks, but adding, in the same sentence, that each sex had its own particular role to perform in society.

Comm. on the Elimination of Discrimination against Women, Summary Record of the 237th meeting, U.N. Doc. CEDAW/C/SR.237, at 9-10, \46 (Mar. 11, 1994).

118 See the statements by Ms. Ivanka Corti on the CEDAW Committee, supra note 112. 
but more generally, and at all times, the notion is that the ultimate goal in the conversation is for the State to withdraw the reservation. And that obligation is based on the Committee's sense of a fixed meaning of equality attached to Article $2 .{ }^{119}$

By questioning the appeal to religion by the state, on the basis of discrimination against women, the Committee is not simply asserting a secular form of equality for men and women. For believers, it is securing a split of the human being as a holder of incommensurable rights. The position of the Committee holds that the Catholic woman, like the Muslim woman, is faced with a choice. She can give up her faith and live in full secular equality. Otherwise, she can have public equality, while she agrees to be oppressed privately. Religious norms and their enforcement are removed from the political discussion and, ironically, become more inscrutable to criticism and possibly to feminists.

The Committee resists and rejects a full-out battle by not taking a hardline position on gender roles within the Christian Churches or the Mosques or any other religious institutions. The Committee resists making the case that until religious doctrine is revised, gender oppression will exist. This old-school feminist position, which boldly takes on the issue of representation and symbolism of women in religion, is not taken up in the debates on women's rights. Or it may be asserted that religion and women's equality are incompatible, as Ms. Corti did, but then the question is what is the state to do? The state

119 In its concluding observations on Oman's periodic report, the CEDAW Committee states:

The Committee also takes note of the assurances given by the State party in the dialogue with the Committee that there is no contradiction between the Sharia and the Convention. The Committee is of the opinion that a general reservation, as well as the reservation to article 16 are contrary to the object and purpose of the Convention and are thus impermissible under article 28 of the Convention (Committee's statement on reservations, A/53/38/Rev.1).

Comm. on the Elimination of Discrimination Against Women, Concluding Observations: Oman, U.N. Doc. CEDAW /C/OMN/CO/1, at 3, ๆ 15 (Nov. 4, 2011).

Similarly, in its recommendations to Kuwait, the Committee states:

The Committee notes the State party's commitment to further improve its legislation and policies to fully implement the provisions of the Convention, which requires, inter alia, that the Islamic sharia be interpreted in accordance with the State party's obligations under the Convention, and that the State party withdraw its reservations to articles 9, paragraph 2, and 16, paragraph 1 (f), of the Convention.

Comm. on the Elimination of Discrimination Against Women, Concluding Observations: Kuwait, U.N. Doc. CEDAW /C/KWT/CO/3-4, at 2, 5 (Oct. 18, 2011). 
must be separate from religion. It seems that the European position is not to engage with the role of women in religion. If it did, the Committee would be asserting that the next Pope should be a woman. Instead, a seeming nod toward pluralism against the backdrop of the separation of church and state, the Committee has only asserted the legal position that state-based religions or religions which blatantly influence state actions should cease to be so public. ${ }^{120}$

Within the CEDAW monitoring process, women's rights advocates are given an

120 Typically, the CEDAW Committee criticizes some norms relating to marriage because they constitute endorsements by the state of religious rules, as an unwelcome alternative to following the rules of the Convention:

\begin{abstract}
An examination of States parties' reports discloses that many countries in their legal systems provide for the rights and responsibilities of married partners by relying on the application of common law principles, religious or customary law, rather than by complying with the principles contained in the Convention. These variations in law and practice relating to marriage have wide-ranging consequences for women, invariably restricting their rights to equal status and responsibility within marriage. Such limitations often result in the husband being accorded the status of head of household and primary decision maker and therefore contravene the provisions of the Convention.
\end{abstract}

Comm. on the Elimination of Discrimination against Women, General Recommendation 21, in Report of the Thirteenth Session, U.N. Doc. A/49/38, at 1 (Apr. 12, 1994). In a similar vein, Committee members question also the influence of religion on public policy, rather than the religion itself, which is, therefore, appropriately left to the private sphere and governed by the freedom of religion. Speaking to the representatives of Croatia, Ms. Chalal stated:

What measures would be taken to ensure that the legal right to abortion was implemented?
The implementation of that right had also been impeded by the influence of the Catholic
Church and conservative groups. Despite a circular from the Ministry of Health reminding
public hospitals that they were obliged to provide abortion services and better regulate
conscience clauses, more than half of gynecologists in 2014 had refused to conduct
abortions according to the Ombudsperson for Gender Equality.

Comm. on the Elimination of Discrimination against Women, Summary record (partial) of the 1320th meeting, at 4, ๆ 14, U.N. Doc. CEDAW/C/SR.1320 (July 23, 2015).

Another problem with religion is diagnosed equally indirectly when the state is not countering what the Committee sees as deleterious effects of religious organizations on the successful implementation of the Convention. To Poland, the CEDAW Committee suggests that it should "[t]ake measures to promote the equal rights of women and combat efforts made by any actors, including the Catholic Church, to downplay or degrade the pursuit of gender equality by labeling such measures as ideology." Comm. on the Elimination of Discrimination against Women, Concluding Observations: Poland, at 6, ๆ 23(d), U.N. Doc. CEDAW/C/ POL/Q/7-8 (Nov. 14, 2014). 
opportunity to be part of a dialogue about religious regulation of gender in countries that have reservations based on Shari'a. Rather than basing women's empowerment on a Liberal politics of secularism, the CEDAW Committee could welcome more generally the opportunity to engage in a dialogue about religion and gender discrimination. It is in fact rare that any religion is subjected to this degree of transparency and openness to outside engagement, and that is precisely because it is state-based. But further, Islamic law is not a closed set of rules that one can determine in a vacuum to be good or bad for women. It is a complex rule system with various principles of interpretation and as such, it is itself open to interpretation and reinterpretation. ${ }^{21}$ But by claiming, or at times suggesting, that the reservations are incompatible with the object and purpose of the Convention, the Committee is saying that Shari'a is a priori fundamentally incompatible with the human rights of women; again, the objective is always to withdraw the reservation, because if it has a purpose, it is to inflect "equality" and therefore cannot stand. The pronouncement has thus already been made, especially when the Committee welcomes state declarations to the effect that Shari'a and CEDAW are compatible, which means necessarily compatible with one specific understanding of equality: formal equality, and substantive equality that does not derogate from formal equality, are universal norms, and therefore religion is not compatible with public international law, with modernity, with universality and, most importantly, cannot be. The paradox is here that the problem is mainly the public and international endorsement of what is considered private faith and therefore any of the newly designated retrogrades who choose to remain or become faithful to a religion must do so privately. As a result, what is rejected is simply the general notion of a superiority of divine law over international law, and meanwhile the management of "equality" and "equity" is wishfully delegated to the private sphere, as if the constitutional order based on the supremacy of divine law was also to be abandoned. Men will agree that to be faithful, they must also accept that they are necessarily oppressors, and women, if believers, agree privately to their own oppression. But if Shari'a is not unequivocally compatible or incompatible with CEDAW - a question that, due to the Committee's ambivalence towards the question, is never really (and fortunately) solved as such — public discussion on their mutual relation should be welcome, precisely because interpretations of Shari'a are as nuanced as interpretations of the idea of gender equality. The problem may be that, for the most part, there has been a systematic assumption of bad faith on the part of Middle Eastern

121 See, e.g., Madhavi Sunder, Piercing the Veil, 112 Yale L.J. 1399 (2003). See also Intisar A. RabB, Doubt in Islamic Law: A History of Legal Maxims, Interpretations, and Islamic Criminal Law (2014). Many comments from within Islamic traditions on the relationship of Islam to human rights point to the notion that the key lies in interpretation and the social context in which it occurs. See, e.g., Amira Mashhour, Islamic Law and Gender Equality —Could There be a Common Ground?: A Study of Divorce and Polygamy in Sharia Law and Contemporary Legislation in Tunisia and Egypt, 27 Hum. RTs. Q. 562, 562-96 (2005). 
governments when constructing alternative Islamic human rights. ${ }^{122}$ "Islamic reservations" may have been taken to be in all cases shields for, at best, a simple lack of commitment and, at worst, a manipulation of international standards for objectives that are completely unrelated to women's rights and welfare.

The Committee instead could assume good faith on the part of the states and assume compatibility with the object and purpose of the treaty. The State has signed onto the principle of non-discrimination against women (as the object and purpose of the treaty) and must therefore show how its own interpretations of Shari'a benefit women and, if they do not, push for interpretations that do. But instead, the objections to "Islamic reservations" represent a response to a perceived threat, which has been itself fabricated by fear of Islamic religiosity and the failings of the States as they are currently organized. It is the problem of linking the state with any religion. The imperfections of state policy become a seeming indictment of the religion.

By asserting a priori that the so-called "Islamic reservations" are incompatible with the object and purpose of CEDAW, the Committee is forced into a maddening circular debate with State representatives. A dialogue with a Libyan representative shows the difficulty. ${ }^{123}$ The dialogue begins with the state representative asserting that Islamic law allows for equality between the sexes. ${ }^{124}$ The Committee then asks why there is then a reservation, if equality is already allowed within Islam. ${ }^{125}$ The Committee then asserts that there

122 See, e.g., Ann Elizabeth Mayer, Islam and Human Rights: Tradition and Politics 3 (5th ed. 2013) ("The opacity in the [Islamic human rights] schemes will be highlighted. It correlates with the way that Middle Eastern governments have for the most part sought to maintain pretenses of respect for international human rights law even while seeking to degrade it.").

123 Comm. on the Elimination of Discrimination Against Women, Consideration of Reports Submitted by States Parties Under Article 18 of the Convention: Libyan Arab Jamahiriya, in Report of the Thirteenth Session, U.N. Doc. A/49/38, at 38-45, ๆๆ 130-85, esp. at 39, ๆ 132 (Apr. 12, 1994).

124 Summary Record of the 237th meeting, supra note 117, at 3, \ 10.

125 Id. at 9,94 :

Since the Libyan Government believed that Islamic law provided more rights to women than national and international legislation, she [Ms. Cartwright] requested that it should consider the possibility of withdrawing those reservations which related particularly to article 2 of the Convention, taking into account the objections of many States parties in that regard. Libya would thus show that it was complying fully with the Convention.

The reservation reads as follows: "Article 2 of the Convention shall be implemented with due regard for the peremptory norms of the Islamic Shariah relating to determination of the inheritance portions of the estate of a 
are different interpretations within Islam and that Shari'a should be read in light of the Convention. ${ }^{126}$ The State representative is asserting that there are different interpretations but that the reservation is maintained because the Convention should be read in light of Islamic Shari'a. ${ }^{127}$ The end result appears to provoke frustration instead of constructive dialogue. While the CEDAW Committee can formulate general comments and weigh in on the way in which states fulfill their treaty obligations, the states only have reservations or

deceased person, whether female or male." Reservations, supra note 55.

126 In the words of Ms. Emna Aouij,

The precepts of the Koran concerning family life, motherhood, family planning and contraception should be reviewed within the framework of an evolving interpretation in order to conform not only with the terms of the Convention, but also with the demands of modern society.

$I d$. at 9, 9ा 43-44. Responding to Morocco's first state report, the Committee notes that the reservations preclude "evolving concepts of Islamic law," without explanation. Comm. on the Elimination of Discrimination Against Women, Consideration of Reports Submitted by States Parties Under Article 18 of the Convention: Morocco, in Report of the Sixteenth Session, U.N. Doc. A/52/38/Rev.1 (Supp.), at 13, ๆ 59.

127 In response to the Committee's questions, this is the Libyan delegate's statement:

One of the aims of Islam was to liberate human beings, both men and women, from all forms of servitude and exploitation. Islam had taken up the cause of women, prohibiting pre-Islamic practices such as the burying of girls alive, and strongly criticized even the expression of displeasure on the birth of a girl child. It had granted women the right to inherit, which they had not previously had, and the right to choose their husband and to keep their name; it also gave them the right to dispose freely of their property. The Koran extolled women who had attained high positions. Islam called for equality among all humans, both men and women; it permitted women to engage in all lawful business practised by men. In respect of worship, too, women had the same duties and rights as men. Any differences that might appear in those areas were positive rather than negative, and neither involved discrimination against women nor impeded their development and advancement. An example was the woman's hereditary portion, which was half the man's share; the woman, however, received her share without any related obligations, while the man was subject to obligations that consumed his entire portion.

Such matters involved precepts which no Muslim, whether man or woman, could alter; violating them was tantamount to violating public order. That was perhaps the underlying reason for the reservation on the part of the Libyan Arab Jamahiriya and other Islamic States. Yet there was ample room for implementing the Convention and complying with its provisions. He believed that an objective dialogue would lead to mutual understanding and dispel the preoccupations of the Committee.

Comm. on the Elimination of Discrimination against Women, Summary Record of the 240th meeting, U.N. Doc. CEDAW/C/SR.240, at 2, ๆๆ 4-6. (Feb. 4, 1994). 
interpretative declarations. A presumption of good faith and acceptance of the reservations could create a different dialogue.

The CEDAW Committee focuses on entrenched oppressive interpretations of Shari'a at times, but then asserts that the openness and multiplicity of interpretations is the problem at other times. ${ }^{128}$ In several state reports, the Committee notes that representatives refer to the openness of Shari'a when reporting. In 1993, the Iraqi representative is noted as pointing out that, "[e]ven if all legislation remained within the purview of the Koran, new interpretations could be found in order to change the policies of the country." 129 This openness should be seen as a strength, in that neither religious law nor human rights law is beyond reinterpretation. ${ }^{130}$ The discursive circle could be closed if the reservations were not argued against as such, but pushed to their logical ends. States must adhere to the object and purpose of the treaty despite the formulation of a reservation: a reservation must be interpreted as far as possible as being in line with the object and purpose of the treaty, which is suggested every time members of the Committee or state representatives insist that Shari'a and CEDAW are perfectly compatible. ${ }^{131}$ Based on its collective expertise, the Committee only has to specify how the state must do that. Neither human rights law nor Islamic law are absolutely stable. The assertion that reservations to human rights treaties erode the very basis of human rights assumes a natural theory of human rights that seems to trump in its dogmatism dogmatic views of religious law. There would be no loss of energy

128 Ms. Mervat Tallawy while on the CEDAW Committee suggested herself that "she was well aware that many members of the Committee did not understand clearly the Islamic Shariah and too often tended to give it a hasty interpretation." Summary Record of the 237th meeting, supra note 117, at 11, $\mid 52$.

129 Comm. on the Elimination of Discrimination Against Women, Consideration of Reports Submitted by States Parties Under Article 18 of the Convention: Iraq, in Report of the Twelfth Session, U.N. Doc. A/48/38 (Supp.), at 18, \ 84 (1993).

130 Lama Abu-Odeh has argued that within Egyptian family law the attention given to certain legal provisions based on Shari'a and regarding marriage, divorce, and inheritance has led to misunderstandings by non-Muslim academics. Within the tradition of Third World feminism, the provisions in family law in which women are treated de jure differently from men, have been a subject of internal debate and critique, as well as of a local concern to defend against the various misunderstandings from the "outside." Abu-Odeh and others, though eager to critique Shari'a-based family law, have also argued that there are overlooked advantages for women within Islamic law when understood in context, as well as tremendous openness for interpretation and reinterpretation. See Lama Abu-Odeh, The Politics of (Mis)recognition: Islamic Law Pedagogy in American Academia, 52 Ам. J. Cомp. L. 789 (2004).

131 Again, while discussing Libya's periodic report, Ms. Tallawy "said that she did not see why those reservations should be upheld out of respect for the Shariah, when the report had emphasized the pioneering role the Shariah had played in promoting women's rights." Summary Record of the 237th meeting, supra note 117 , at 10,952 . 
to go through the motions of requesting the state to remove the reservation. The Committee would shift the burden to the State party to show how the state is promoting equality between men and women. Any deviation would otherwise be contrary to the object and purpose of the treaty. The discussion is not about Shari'a as an abstract concept but instead a productive discussion about the laws in practice.

The rejection of public endorsement of religion is a rejection of pluralism both in the interpretation of Islamic law and in the interpretation of Articles 2 and 16 of CEDAW. Pluralism based on only one kind of political system is not pluralism at all at the international level. Rejection of pluralism is a negation of an existing debate in both, and primarily within States that - at least if seen from the assumption of good faith-feel the necessity of keeping a space open for discussion in civil society.

Although the Committee has made great strides to pierce the public/private distinction and deal with private actors in cases of violence against women, ${ }^{132}$ that is not necessarily the case when economics are concerned. The language the Committee uses when scrutinizing private activity that leads to economic differences that are not immediately related to public endorsement of religion is very different from the terms in which it addresses public, religious personal status laws that appear to be de jure unequal or discriminating.

In this context, it will be interesting to see what the Committee does with the reservation made by Micronesia, which excludes the application of parts of Article 2 on the basis that there is no state obligation to intervene in any division of roles in the family between men and women, when those divisions are made as purely voluntary or consensual private conduct. ${ }^{133}$ This reservation goes to the heart of the issue, whether unequal treatment

132 See, e.g., A.T. v. Hungary, CEDAW Commc'n No. 2/2003, U.N. Doc. CEDAW/C/32/D/2/2003 (Jan. 26, 2005); Fatma Yildirim (deceased) v. Austria, CEDAW Commc'n No. 6/2005, CEDAW/C/39/D/6/2005 (Oct. 1, 2007); Sahide Goekce (deceased) v. Austria, CEDAW Commc'n No. 5/2005, U.N. Doc. CEDAW/ C/39/D/5/2005 (Aug. 6, 2007).

133 The relevant segment of the reservation reads as follows:

The Government of the Federated States of Micronesia, in its capacity as trustee of the heritage of diversity within its States under Article V of its Constitution, reserves the right not to apply the provisions of Articles 2 (f), 5, and 16 to the succession of certain wellestablished traditional titles, and to marital customs that divide tasks or decision-making in purely voluntary or consensual private conduct.

It has been objected to by Finland, Sweden, and Portugal. See Reservations, supra note 55. Micronesia was due to submit its initial and second periodic reports in 2005 and 2009 respectively. See Comm. on the Elimination 
between men and women, if constructed as privately consensual, is to be treated as beyond the scope of the treaty.

\section{Public versus Private Religion}

The debate around the public/private distinction in women's rights has focused almost exclusively on violence against women. ${ }^{134}$ It is about the ways in which private individuals assault women. However, the critique of the public/private distinction in law is extensive and it is worth assessing the different ways in which women can be oppressed. ${ }^{135}$

The reservations based on Shari'a and practice of state parties like Egypt that place religious law as a source of law in their constitutions call attention to religion in a specific way that does not happen explicitly in the case of (other) religions in secularized political systems. There, religion is seen largely as a private affair, either by default or by constitutional mandate. However, CEDAW is supposed to be exceptional in its ability to transcend the public/private distinction, making states responsible for private action that regulates and structures gender norms and stereotypes. ${ }^{136}$ This is certainly the case

of Discrimination Against Women, Status of submission of reports by States parties under article 18 of the Convention, Report of the Secretary-General, U.N. Doc. CEDAW/C/48/2 (Nov. 24, 2010). At the time of writing, Micronesia had submitted its report, but the Committee had not hosted the Micronesian delegation yet. Comm. on the Elimination of Discrimination Against Women, Summary record (partial) of the 1333rd meeting, U.N. Doc. CEDAW/C/SR.1333, at 3, ๆ 14 (Oct. 28, 2015).

134 Catherine Moore, Women and Domestic Violence: The Public/Private Dichotomy in International Law, 7 Int's J. Hum. Rts. 93 (2003); Christine Chinkin, A Critique of the Public/Private International Law, 10 Eur. J. INT'L L. 387 (1999); Romany, supra note 110.

135 See, e.g., Duncan Kennedy, The Stages of Decline of the Public/Private Distinction, 130 U. Penn. L. Rev. 1349 (1982); Public and Private: Legal, Political and Philosophical Perspectives (Maurizio Passerin d'Entrèves \& Ursula Vogel eds., 2000).

136 Article 5 of CEDAW instructs state parties:

(a) To modify the social and cultural patterns of conduct of men and women, with a view to achieving the elimination of prejudices and customary and all other practices which are based on the idea of the inferiority or the superiority of either of the sexes or on stereotyped roles for men and women;

(b) To ensure that family education includes a proper understanding of maternity as a social function and the recognition of the common responsibility of men and women in the upbringing and development of their children, it being understood that the interest of the children is the primordial consideration in all cases. 
with violence against women, as feminist critiques have managed to make actions of private individuals visible in international law for which the state is responsible. ${ }^{137}$ Yet,

CEDAW, supra note 1.

137 Domestic violence is now uncontested as a major human rights issue, which was not the case in the recent past. The Organization of American States adopted a treaty on domestic violence in 1994. See Inter-American Convention on the Prevention, Punishment and Eradication of Violence Against Women, June 9, 1994, 33 I.L.M. 1534. The Council of Europe followed in 2011. See Convention on Preventing and Combating Violence against Women and Domestic Violence, May 11, 2011, E.T.S. No. 210. Both texts are legally founded on the principle of due diligence, known in general terms as the "duty to protect," alongside the "duty to respect," and famously described in general terms by the Inter-American Court of Human Rights. See Velásquez Rodríguez Case, Judgment, 1988 Inter-Am. Ct. H.R. (ser. C) No. 4, $₫ 172$ (July 29, 1988):

Thus, in principle, any violation of rights recognized by the Convention carried out by an act of public authority or by persons who use their position of authority is imputable to the State. However, this does not define all the circumstances in which a State is obligated to prevent, investigate and punish human rights violations, nor all the cases in which the State might be found responsible for an infringement of those rights. An illegal act which violates human rights and which is initially not directly imputable to a State (for example, because it is the act of a private person or because the person responsible has not been identified) can lead to international responsibility of the State, not because of the act itself, but because of the lack of due diligence to prevent the violation or to respond to it as required by the Convention.

See also Soc. \& Econ. Rights Action Ctr. (SERAC) v. Nigeria, Commc'n No. 155/96, Case No. ACHPR/ COMM/A044/1, Afr. Comm'n Human \& Peoples’ Rights, ๆ 44 (May 27, 2002):

Internationally accepted ideas of the various obligations engendered by human rights indicate that all rights, both civil and political rights and social and economic, generate at least four levels of duties for a State that undertakes to adhere to a rights regime, namely the duty to respect, protect, promote, and fulfil these rights. These obligations universally apply to all rights and entail a combination of negative and positive duties .... At a primary level, the obligation to respect entails that the State should refrain from interfering in the enjoyment of all fundamental rights .... At a secondary level, the State is obliged to protect right-holders against other subjects by legislation and provision of effective remedies. This obligation requires the State to take measures to protect beneficiaries of the protected rights against political, economic and social interferences. Protection generally entails the creation and maintenance of an atmosphere or framework by an effective interplay of laws and regulations so that individuals will be able to freely realize their rights and freedoms.

(emphasis in original). Successive U.N. Special Rapporteurs on Violence Against Women have promoted the notion of state responsibility for acts of private actors as a legal basis for making domestic violence into a question of public policy. See Yakin Ertürk (Special Rapporteur on Violence Against Women), The Standard of Due Diligence as a Tool for the Elimination of Violence Against Women, U.N. Doc. E/CN.4/2006/61 (Jan. 20, 2006); Rashida Manjoo (Special Rapporteur on Violence Against Women), State Responsibility for 
beyond violence against women, religion as an institution structures and constitutes gender relations, but there is no explicit state obligation to take on religious reform to meet treaty obligations to CEDAW in countries where religion is a more apparently private matter. ${ }^{138}$ Nor do states or the Committee consistently employ a gender perspective when looking at the church, the temple, or the synagogue as part of their perceived obligations to international law, in a way that would require active reformist interference by the state. What the CEDAW Committee does not tolerate under the banner of the object and purpose of the Convention is the state explicitly and publicly yielding to religion under the umbrella of a reservation. ${ }^{139}$ Under the human rights framework, as long as religion remains private, it seems to be (largely) beyond the international rights agenda. ${ }^{140}$ It is the public/private

Eliminating Violence against Women, U.N. Doc. A/HRC/23/49 (May 14, 2013). The first report of the first Special Rapporteur addressed "violence in the family" as its first topic. See Radhika Coomaraswamy (Special Rapporteur on Violence Against Women), Further Promotion and Encouragement of Human Rights and Fundamental Freedoms, Including the Question of the Programme and Methods of Work of the Commission, U.N. Doc. E/CN.4/1996/53 (Feb. 5, 1996). In addition, the European Court of Human Rights has also had the opportunity of finding state parties to the European Convention in breach of their obligations in cases of domestic violence, and namely in breach of the prohibition of torture. See, e.g., Valiuliene v. Lithuania, Judgment, Application No. 33234/07, Mar. 26, 2013. In that case, the Court considered that the failure to address appropriately a complaint for domestic abuse made the State international responsible for the fact that acts of violence were committed against a women, which would have been considered acts of torture if committed by state organs: "In the Court's view, the practices at issue in the present case, together with the manner in which the criminal-law mechanisms were implemented, did not provide adequate protection to the applicant against acts of violence. Therefore the Court finds that there has been a violation of Article 3 of the Convention." Id.

138 As mentioned above, what we find in the CEDAW Committee's practice is a demand on the state to keep religious influence at bay. See supra note 1.

139 Rep. of the Comm. on the Elimination of Discrimination against Women of Its Thirty-Second and Thirty-Third Sessions, U.N. Doc. A/60/38, at 133 \ 145 (2005):

The Committee remains concerned that the State party continues to retain its reservations to articles 7 (b) and 16 of the Convention. The Committee is particularly concerned at the State party's statement that such reservations are "unavoidable at this point in time" and its position that laws based on religious values cannot be reformed.

The Committee urges the State party to consider withdrawing its reservations to articles 7 (b) and 16, which are contrary to the object and purpose of the Convention.

140 The already mentioned General Recommendation No. 28, supra note 68, focuses special attention on the public/private distinction, insisting that states are responsible for discrimination against women whether by its act or omission and extending through a due diligence standard to acts and omissions by private actors. It is significant that the public/private distinction is something the Committee members are consciously theorizing while at the same time appear to overlook it when it comes to the way religious beliefs influence gender in 
distinction, as a recurrence of the politically visible and invisible, that makes Islamic law such a target in the women's rights debate. ${ }^{141}$

Evidence of the way in which the public/private binary works to hide gender oppression in secular states and calls attention to religious state law can be found in the CEDAW Committee responses to state reports. The Committee has taken the explicit stance that reservations to CEDAW based on religion do not suggest that what is required is a reform of the said religion as such, but rather that religion should be removed somehow from the visible state structure. Commenting on Israel's first and second reports, the Committee wrote the following: "in order to guarantee the same rights in marriage and family relations in Israel and to comply fully with the Convention, the Government should complete the secularization of the relevant legislation, place it under the jurisdiction of the civil courts and withdraw its reservations to the Convention." ${ }^{142}$ The meaning of the instruction to "secularize" is not clear. Again, the Committee is not banning religion, and a few members of the Committee have, as mentioned above, taken the position that religion is supportive of women's rights. But this creates contradictions. Presumably, individuals would still be able to obtain religious marriages, and still be able to follow religious doctrine in their familial relations under the banner of the freedom of religion, which state parties have to make special efforts to protect under Article 3 of CEDAW. But the Committee does not want states to shield freedom of religion from a particular interpretation of gender equality/ equity. Following the argument of the Committee to its logical end, it appears that it would be possible for private individuals to continue to avail themselves privately of unequal treatment through religious institutions, as long as it is not linked directly to the state. Or at the very least there is a sequencing issue by which the Committee should clarify that the removal of formal differential treatment must be followed up with a program to transform the unequal treatment in religious doctrine. The state still has the duty to eliminate "harmful practices" based on religion, ${ }^{143}$ on the grounds that, as it says, "[n]either traditional, religious

secular societies, as opposed to societies in which religion is more present in the public sphere.

141 The controversies over the "Muslim veil" in Europe are structured around one visible symbol that is read as gender oppression. As Pamela Slotte puts it, "[Women] are made to represent foreign religiosity that is considered threatening, as it seems to challenge established conceptions of faith and of modern Western secular societies." Pamela Slotte, Women, Human Rights, Religion, 2 Helsinki Rev. Global Governance 30, 35 (2011).

142 Rep. of the Comm. on the Elimination of Discrimination against Women on Its Seventeenth Session, U.N. Doc. A/52/38/Rev.1, Part II, ๆ 173 (July 25, 1997).

143 Yakin Ertürk (Special Rapporteur on Violence Against Women), Cultural Practices in the Family that are Violent Towards Women, U.N. Doc. E/CN.4/2002/83 (Jan. 31, 2002). 
or cultural practice nor incompatible domestic laws and policies can justify violations of the Convention." ${ }^{144}$ In that sense, CEDAW intervenes just enough to address the problem, but not enough to combat it: rather than engage with religion, the Committee appears to exclude it from the conversation. As a result, religion, which is acknowledged through the reservations debate as a potential source of inequality, is left to the individual private sphere and out of the social sphere and public arena. Gender oppression may not then be state oppression and may not even be as widespread as when it is backed by the state political and legal structure. But, it is in many ways far more pernicious. So, a form of state-backed gender oppression that is read into the "Islamic reservation," transforms into a matter for personal choice that is not subject to public scrutiny in the constructive dialogue between the CEDAW Committee and state parties. And by the same token CEDAW becomes the conveyor of a peculiar political ontology of women: to the extent that women choose equity over equality, they are rational actors, fallen victims of false consciousness and seemingly beyond the mandate of the committee. The fundamentals of equality cannot be discussed. At the point where CEDAW meets public religion, decades of feminist internal debates have been resolved into one position.

The CEDAW Committee appears thus uncomfortable with links between religion and the state and this at times seems to structure the types of interventions made. Secularism as a reflex paints the world of the visible and invisible. In states such as Egypt, where there are religious minorities, attention often focuses not on the forms of gender oppression across religions but on the form of oppression that directly emanates from dominant religion and the state structure. So, for example, there is less attention paid to the norms that govern Coptic marriage, despite oppressive rules and norms structuring women's lives, and the fact that there is no mention of Coptic religious law in the language of Egypt's reservation to Article 2. One wonders whether there would be a conversation about it between the CEDAW Committee and Egypt if the reservation were thus not absent, but rather more extensive. And one has to wonder here if the reservation would not be a tool for a conversation also within Egypt, as the present conversation already is among feminists, Islamic or otherwise, in Egypt.

Now, based on the above, what happens if a state intervenes precisely to secularize the public sphere, against the claims of freedom of religion? In the case of legislation banning religious, gender-specific symbols, such as veiling in Belgium, the CEDAW Committee comes up against a difficult problem. The Committee does not take a stance on whether veiling is gender oppression per se, but rather uses the more cautious language

Statement on Reservations, supra note 70, $₫ 17$. 
requiring states to assess the situation: "[t]he Committee recommends that the State party monitor and assess the impact on women and girls, in particular in relation to their access to education and employment, of the ban on wearing headscarves adopted by several local administrations . . .."145 It is not quite clear that under the mandate of CEDAW, the Committee realizes that there is precisely a potential of discriminatory curtailing of religious rights, because Muslim women who want to practice their religion may want to do so by wearing a scarf in public. CEDAW has repeatedly asked Turkey to provide statistical data to demonstrate that women and girls are not adversely affected by the ban on headscarves, and it has expressed concerned over that possibility. ${ }^{146}$ But it has not made a decision on the issue, which should not be surprising. The contrast with the European Court is instructive concerning the pitfalls of an implausibly coherent line on religion in the public sphere. The Court has systematically upheld bans on headscarves (or niqqab), including the Turkish ban. This line of interpretation is based on two elements that are latent in CEDAW's practice: (1) in contrast to CEDAW's instinctive concern for women being denied agency, the Court clearly (and despite what it explicitly says) substitutes itself for women in deciding what counts as practicing religion (which constitutes a mixture of paternalism and assuming false consciousness, on top of ruling on what constitutes the core of a religion) ${ }^{147}$ and (2) in contrast to CEDAW's position on universalism,

145 Comm. on the Elimination of Discrimination against Women, Concluding Observations of the Seventh Periodic Report of Belgium, U.N. Doc. CEDAW/C/BEL/CO/7, Part C, $\mid 19$ (Nov. 14, 2014).

146 Comm. on the Elimination of Discrimination against Women, Concluding Observations: Turkey, U.N. Doc. CEDAW/C/TUR/CO/6, ๆ 16-17 (July 30, 2010).

147 In deciding on a ban of niqqab in France, the Court admits that it is an interference with the freedom of religion, and thus must pass the test of legitimate aim and proportionate means. In this case, the aims that justify the ban are public safety, but more importantly democratic pluralism. The question then is whether the means are proportionate, and it revolves around how intrusive of an interference it is. This is the response:

Thus, while it is true that the scope of the ban is broad, because all places accessible to the public are concerned (except for places of worship), the Law of 11 October 2010 does not affect the freedom to wear in public any garment or item of clothing - with or without a religious connotation - which does not have the effect of concealing the face. The Court is aware of the fact that the impugned ban mainly affects Muslim women who wish to wear the full-face veil. It nevertheless finds it to be of some significance that the ban is not expressly based on the religious connotation of the clothing in question but solely on the fact that it conceals the face.

S.A.S. v. France, 2014-III Eur. Ct. H.R. 695, ๆ 151.

The most important element is that a few paragraphs before, the Court insists that Muslim women do not have to justify that wearing the niqqab is demanded by their religion. Their opinion is the only one that matters. 
the Court relies on the "margin of appreciation" of states in dealing with the extent of democratically appropriate interferences with rights, such as the right to privacy and the right to freedom of religion. ${ }^{148}$ The treatment of religion and gender leads to aberrations: states are allowed to defend prohibitions that affect only women, on the basis of the state's preferred ideology of anti-religion; ${ }^{149}$ and moreover states are not allowed, in the name of pluralism and secularism, to intervene in religious matters, which are private, but then they (or the Court) have to decide what counts as religion precisely to decide where individual choice went wrong. And just as we see it looming in CEDAW's practice, we have already witnessed it in the Court's decisions: headscarves can be banned in the name of secularism (in Sahin v. Turkey) or democratic pluralism (in S.A.S v. France), but crucifixes can stay in the classroom (in Lautsi v. Italy), based on reasons that should also apply to headscarvesexcept that headscarves are not crucifixes. ${ }^{150}$

But then, because we are measuring proportionality, this pushes the Court to question whether the niqqab is really a demand, as opposed to a choice or "wish."

148

The national authorities have direct democratic legitimation and are, as the Court has held on many occasions, in principle better placed than an international court to evaluate local needs and conditions. In matters of general policy, on which opinions within a democratic society may reasonably differ widely, the role of the domestic policy-maker should be given special weight .... This is the case, in particular, where questions concerning the relationship between State and religions are at stake... . As regards Article 9 of the Convention [i.e. freedom of conscience and religion], the State should thus, in principle, be afforded a wide margin of appreciation in deciding whether and to what extent a limitation of the right to manifest one's religion or beliefs is "necessary". That being said, in delimiting the extent of the margin of appreciation in a given case, the Court must also have regard to what is at stake therein ... . It may also, if appropriate, have regard to any consensus and common values emerging from the practices of the States parties to the Convention.

Id. ๆ 129 (internal references omitted). See also Sahin v. Turkey, App. No. 44774/98, 44 Eur. H.R. Rep. 99, ๆ 109 (2005).

149 Sahin v Turkey, App. No. 44774/98, 44 Eur. H.R. Rep. 99, $\rrbracket 114$ (2005):

[U]pholding that principle [i.e. secularism], which is undoubtedly one of the fundamental principles of the Turkish State which are in harmony with the rule of law and respect for human rights, may be considered necessary to protect the democratic system in Turkey. An attitude which fails to respect that principle will not necessarily be accepted as being covered by the freedom to manifest one's religion and will not enjoy the protection of Article 9 of the Convention 
And so even when the CEDAW Committee criticizes the influence of non-state religions, such as the Catholic Church (outside the Holy See), it is often on the basis of it acting like a state-religion, which is the only standard that seems to provide a modicum of stability. In a concluding observation on Ireland the CEDAW committee offers the following:

The Committee notes that although Ireland is a secular State, the influence of the Church is strongly felt not only in attitudes and stereotypes but also in official State policy. In particular, women's right to health, including reproductive health, is compromised by this influence. The Committee notes that Ireland did not enter a reservation to article 12 upon ratification of the Convention. The Committee recommends implementation of this article in full. ${ }^{151}$

It is an ironic move made by the Committee, and it almost seems tongue in cheek. Ultimately, what the Committee is saying is that it finds fault in Ireland for not having placed a reservation to the Convention, while noting that the real problem is that the church is influencing state policy like a state-based religion. Again, instead of arguing against the political position held by the Church (as a political entity), which constitutes the Irish state's own position on abortion, the Committee argues against the role of the Church in state politics. But that does not address the question of individual women making their own interpretation of equality through the prism of religion, and the necessity of having a debate about it; as shown by the European Court and CEDAW, in a less dramatic fashion, everything converges towards a denial of women's agency within religion, and their liberation through a form of militant liberalism and pluralism endorsed by default in the framing of women's rights.

Lama Abu-Odeh has argued that within Egyptian family law the attention given to certain legal provisions based on Shari'a and regarding marriage, divorce, and inheritance has led to misunderstandings by non-Muslim academics. ${ }^{152}$ Within the tradition of Third World feminism, the provisions in family law, in which women are treated de jure differently from men, have been a subject of internal debate and critique, as well as a local concern defended against the various misunderstandings from the "outside." 153

151 Rep. of the Comm. on the Elimination of Discrimination against Women on Its Twentieth and TwentyFirst Sessions, at 62, ๆ 180, U.N. Doc. A/54/38/Rev.1 (1999).

152 See especially Lama Abu-Odeh, The Politics of (Mis)recognition: Islamic Law Pedagogy in American Academia, 52 Ам. J. СомР. L. 789 (2004).

153 See generally Nesiah, supra note 98. 
As Vasuki Nesiah has argued, instead of taking religiosity and secularism as given points that human rights must then negotiate around, we should understand the ways in which secularism and religiosity are being interpreted and constituted by the field of human rights. ${ }^{154}$ The field of human rights, or at least the practice of the CEDAW Committee, is entrenching, if not constituting, a public/private distinction in which women's oppression may flourish in private religious institutions veiled behind a construction of private consent. At the same time, women cannot escape the fate of false consciousness or loss of agency, which results in a sense of constant re-victimization and de-responsaibilization of women, even when (or because) they themselves demand the respect of their religious rights.

\section{B. Persistent Blindspots in the Debate: Women's Preferences}

Despite the fact that CEDAW as a treaty is revolutionary in the first place because it is capable of holding states accountable for the actions of non-state actors, and the Committee in principle pays attention to both de jure and de facto discrimination, the Liberal interest of formal equality places the emphasis on the elimination of de jure differential treatment. ${ }^{155}$ Even though the Committee, on the basis of the obligation of due diligence and the mandate of ending social discrimination, does press state parties for sociological data, de jure differential treatment remains more accessible to external scrutiny. An NGO writing a shadow report needs to go no further than show the existence of de jure differential treatments between men and women, and this easily translates to the CEDAW Committee. However, when there are formally equal rules, but differences still persist between men and women, a complicated analysis of why there are more men than women CEOs, for example, must be done. Without the insights of radical or postmodern feminism it is sometimes difficult to move beyond the construct of personal choice as a shield for de facto differences - or seeming differences of preference. It is not quite clear that a formalistic relationship to Article 2 (or Article 16) and "Islamic reservations," and a seemingly dogmatic approach to the relationship between legal systems outside of their actual sociological reality fits what the Special Rapporteur on Violence against Women has described as a major shift away from framing narrowly the problem of culture and victimizing women as passive recipients of violence:

There has been a general tendency in human rights work to treat violence

$154 I d$.

155 Activists have noted the difficulty in getting the CEDAW Committee to recognize harms perpetrated by non-state actors in other contexts. See Caroline Lambert, Partial Sites and Partial Sightings: Women and the UN Human Rights Treaty System, in Global Issues: Women AND Justice 136, 145-46 (Sharon Pickering \& Caroline Lambert eds., 2004). 
against women (VAW) largely within a welfare/humanitarian paradigm, or to view women as "poor victims" in need of protection. In addition, with the adoption of the "harmful traditional practices" agenda by the United Nations in the 1980s, VAW came to be associated with traditional societies, thus de-linking the problem from structural inequalities inherent in existing gender relations. The VAW mandate has contributed significantly to the growth of human rights jurisprudence beyond such narrow conceptual understandings of the problem. ${ }^{156}$

By looking at the religious practices in their legal formulation and outside of their context - which may well be a potential constraint but also a demand of the international process - the Committee may be thus inadvertently making the situation worse for women, simply because it has to rely on some hidden ontology of women, which corresponds to the formal universalist understanding of equality that it has read into Article 2. There are in that sense persistent blind spots in the debate surrounding "Islamic reservations," which exacerbate the higher level of scrutiny on Islamic forms of gender oppression, simply because Islam gets mentioned by name in reservations. And paradoxically, the rejection of the reservation is taken to mean a disappearance of the practices, whereas the CEDAW Convention mandates a separate and much more painstaking work of changing social and private attitudes that contribute to inequality. In other words it is an assertion of superiority of CEDAW's interpretation of equality, which is of course vague enough to encompass all of its members' views, over religion in the abstract.

\section{Modernizing Women's Choices}

Within women's human rights, there has been an implicit privileging of the modern, civilized, and secular civil society at the expense of the "backward" concepts and institutions of tradition, culture, custom, and religion. ${ }^{157}$ Tradition is read as analogous, that is, functioning similar to, culture, and likewise to religion. Tradition, culture and religion are examples or instantiations of the local in a global world. In each case there is a conceptual couple, an opposite that plays in the discourse as an alternative institutional framework or modality of being. Culture as an enemy of women has been an underlying

156 Yakin Ertürk (Special Rapporteur on Violence Against Women), Fifteen Years of The United Nations Special Rapporteur on Violence against Women, Its Causes and Consequences (1994-2009)-A Critical Review, U.N. Doc. A/HRC/11/6/Add.5, at 33 (May 27, 2009).

157 The reading of progress into the history and practice of human rights is an important theme of postcolonial critiques, and in particular Third-World-Approaches-to-International-Law scholarship. See, e.g., Makau Mutua, Savages, Victims and Saviours: The Metaphor of Human Rights, 42 Harv. InT'L L.J. 201 (2001). 
theme for critique in the field of human rights for some time. As former Special Rapporteur on Violence against Women Yakin Ertürk puts it:

[T]here has also been a tendency on the part of some to essentialize traditional cultures of the Global South as inherently harmful to women. Rights law has been perceived as an instrument to eliminate "harmful traditional practices". Such an approach not only fortifies a superficial duality between modernity and tradition but it also assumes that eliminating the practice on its own will serve to liberate the "victimized women" of these cultures. Furthermore, it overlooks the economic and political underpinnings of women's subordination and the construction of culture within the dynamics of power relations at local, national and global levels. Cultural essentialism also ignores the agency of women in the developing world and the trajectories of their resistance to violence and oppression. ${ }^{158}$

Tradition is opposed to the modern, culture to civilization, and religion to civil society. The ways in which human rights treaty bodies deal with these three forms or institutions is instructive for understanding the place of the local in international law. The privileging of these concepts and institutions relies on deep structures and can be seen working throughout society. The complicated relationship in law between gender and tradition, culture or religion continues to trouble people working in the field of women's rights. It has been two decades since feminists and others began debating the tricky relationship of gender to culture. ${ }^{159}$ To this, one must add the contribution of research working out the intersectionality of different identities or social positions such as women in the Third World. ${ }^{160}$

However, in practice we remain ensconced in a discourse of modernization. Although global players seem to have left the "culture" language aside, the binaries of modernity have not disappeared as they are recoded and re-articulated, even into the practice of human rights bodies dedicated in many ways to the rejection of such harmful binaries in the social construction of women. Premised upon the idea of human progress, human rights

158 Ertürk, Standard of Due Diligence, supra note 137, at 9, ๆ20.

159 See generally Karen Engle, Female Subjects of Public International Law: Human Rights and the Exotic Other Female, 26 New Eng. L. Rev. 1549 (1992).

160 See generally Deckha, Is Culture Taboo?, supra note 16. 
are supposed to move us from human wrongs to human rights. ${ }^{161}$ The idea of disciplinary progress is built into professional legal practice as always moving towards something new, something modern, and something ultimately better. ${ }^{162}$ Embedded in the latest articulation of modernity is a conception of economic and human development. ${ }^{163}$ Development and modernizing are thus coupled to constitute a specific form of gender equality. ${ }^{164}$ One could add that within this view of culture, or of tradition or even religion, when juxtaposed against the modernity and development there is an assumption that transcendence is inevitable. But, as Talal Asad has argued, tradition is not a stage of social development, but rather a dimension of society. ${ }^{165}$ However different the mechanisms and iterations, this conception

161 See David Kennedy, The Dark Sides of Virtue: Reassessing International Humanitarianism 352-53 (2004).

162 On the important notion of "progress narration" in international law, see David Kenney, History of an Illusion: International Law in the Nineteenth Century, 17 QuinNIPIAC L. Rev. 99 (1997). Kennedy suggests that the Liberal faith in progress takes in international law the methodological form of a disciplinary history built teleologically, "a disciplinary practice of progress narration which continually restates international law forward of what can then be remembered as the nineteenth century." Id. at 105. Robert Gordon describes more generally uncritical historiography in various modalities as being united by the notion that:

[T]he causal responsibility for change lies with impersonal forces of historical "becoming." More specifically, the histories of certain advanced Western societies, most notably the United States, describe an evolutionary development that is both natural (in the sense that some version of it will happen in every society unless "artificial" constraints force a deviation) and, on the whole, progressive.

Robert Gordon, Critical Legal Histories, 36 Stan. L. Rev. 57, 62 (1984).

On human rights as an element of a civilizational progress narrative, see, e.g., Ratna Kapur, Human Rights in the 21 $1^{\text {st }}$ Century: Take a Walk on the Dark Side, 28 Sydney L. Rev. 665 (2006).

163 The CEDAW Committee has integrated overseeing the implementation of the Millennium Development Goals (MDGs) into their mandate, on the basis of the MDGs' use of CEDAW as a measure of realizing gender equality (goal 3) and more generally the objective respecting all human rights and the promotion of the rule of law. See, e.g., Comm. on the Elimination of Discrimination Against Women, Concluding Observations: Bahrain, U.N. Doc. CEDAW/C/BHR/CO/2, $₫ 43$ (Nov. 14, 2008). See more generally the CEDAW Committee's statement on the link between CEDAW and the MDGs in Comm. on the Elimination of Discrimination Against Women, Report on its Fifty-Fifth, Fifty-Sixth, and Fifty-Seventh Sessions, U.N. Doc. A/69/38 (Suppl.), at 80.

164 As in the case of gender equality and CEDAW, it has made been clear by critics that the development process envisaged by the MDGs is one manufactured version of development in a complex debate. See, e.g., Sakiko Fukuda-Parr et al., The Power of Numbers: A Critical Review of Millennium Development Goal Targets for Human Development and Human Rights, 15 J. Hum. Dev. \& Capacities 105 (2014).

165 Saba Mahmood, Interview with Talal Asad: Modern Power and the Reconfiguration of Religious Traditions, 5 Stan. Electronic Human. Rev. no. 1 (1996), http://www.stanford.edu/group/SHR/5-1/text/asad. 
of human progress in human rights bears some discursive and structural similarities to old empire.

Like colonialism, human rights discourse contains implicit assumptions about the nature of civilized and backward societies, often glossed as modern and traditional. Concepts of civilization and savagery, rationality and passion, that were fundamental binaries of thinking during the imperialist era creep back into debates over human rights and social justice. ${ }^{166}$

Take for example the case of polygamy. The Committee is categorical in its opposition to the practice of polygamy, which it considers unjustified discrimination against women. ${ }^{167}$ In an exchange with Iraq in 1993 the Committee commented negatively on the state's use of loans as an economic incentive to encourage men to marry war widows. Despite the various advantages that polygamy may offer widowed women and their children after a prolonged war in a context of low divorce rates, relatively few living men, few extramarital sexual options, and difficulties in economically sustainable families headed by women, the Committee requested the abolition of this practice. The Committee did not address the ways in which the institution is used, but "it was commented that such an encouragement of polygamy was unacceptable. Asked whether the decree had been promulgated and whether its provisions were subject to any limitations, the representative said that it was of a temporary nature and had been put into force for the protection of women before the outbreak of the war," and the state representative noted that polygamy is "allowed only under certain very strict conditions" and that, "[i]n case of noncompliance, the consequences were three to five years imprisonment for the husband and the possibility for the wife to ask for divorce." ${ }^{\prime 68}$ The Committee noted that there was no information about what the women in Iraq thought about polygamy. ${ }^{169}$ They did not ask for any information in

html [perma.cc/27AG-VHN3].

166 Sally Engle Merry, Human Rights and Gender Violence: Translating International Law into Local Justice 226 (2006).

167 "Polygamous marriage contravenes a woman's right to equality with men, and can have such serious emotional and financial consequences for her and her dependents that such marriages ought to be discouraged and prohibited." General Recommendation 21, supra note 120, ๆ 14.

168 Concluding Observations: Iraq, supra note 129, at 13, ๆๆ 78-79.

$169 I d .979$. 
this case of what the widows thought of this policy or what first wives may think either. ${ }^{170}$ There was also no apparent alternative suggestion by the Committee as to what Iraq should do with war widows with either their economic situation or the lack of romantic and sexual possibilities after being made widows by war. ${ }^{171}$

The move to the modern has been called the "rhetoric of development" by Lila AbuLughod. In an ethnography of Egyptian society she describes the deployment of the rhetoric whereby class politics get recast when access to full citizenship through education or through the modern also tends to go along with the renunciation of family, roots, and the "ignorance" of rural life. ${ }^{172}$ Following the argument of Abu-Lughod, an appeal to modernity is an appeal to emancipation through development, through enlightenment, but at the expense of the traditional. ${ }^{173}$ Abu-Lughod does her ethnography through the images and stories of Egyptian television. It seems not coincidental that the Committee's recommendations to Egypt heavily emphasize the role that the media plays in creating "traditional" stereotypes of women and the media's ability to sow the seeds of cultural transformation. Perhaps part of this explanation is that Egypt is the center of film and television production in the Arabic-speaking Middle East. The Committee responded to Egypt's report by requesting the state to "support the important role of the media in changing stereotypical attitudes towards women .... It recommends that opportunities be created for the portrayal of positive, non-traditional images of women and that the number of women in decision-making positions in the media be increased." ${ }^{274}$ Implicit in all of this is the way in which the modern woman is the woman who participates in the formal market.

170 See, e.g., Anne Hellum, Women's Human Rights and African Customary Law: Between Universalism and Relativism, Individualism and Communitarianism, 10 Eur. J. Dev. Res. 88 (1998) (discussing possible justification of polygamy from the point of view of the welfare and well-being of women in given contexts).

171 The phenomenon of polygamy is increasing again now and it seems that there is a split in the human rights community in Iraq about the desirability of the practice and the renewal of economic incentives for men who marry war widows. However, what is prominent is the use of the term "backwards" in reference to the practice. See Wassim Bassem, Rising Income Means Many Men Marry Multiple Wives, Al-Monitor, Jan. 25, 2015, http://fares.al-monitor.com/pulse/tr/originals/2015/01/iraq-polygamy-men-marriage-society.amp.html [perma.cc/Y3DA-F42G].

172 Lila Abu-Lughod, Dramas of Nationhood: The Politics of Television in Egypt 87 (2008).

173 Id.

174 Comm. on the Elimination of Discrimination Against Women, Rep. on its Twenty-Fourth and TwentyFifth Sessions (2001), U.N. Doc. A/56/38 (Supp.), Part I, at 30, 33, ๆๆ 334-35. 
The privileging of the modern here is not without costs. The juxtaposition of the modern woman against the traditional woman is a juxtaposition of class positions. This renunciation of the ignorance of traditional life actually means the renunciation of "traditional" ways of knowing, and possibly lower or working class values. Instead of opening up possibilities for women, it both opens and closes doors. However, it is not merely a different conception of woman, but the freedom of individual beings, that is at stake. There are knowledge and occupations at the loci of power that are excluded by the political project of re-inscribing the roles of women by privileging the modern. As religion occupies the role of culture and tradition, the project to place women outside this world further entrenches religion as the world of men. ${ }^{175}$ By embracing the modern in form, it may be difficult for women to access traditional occupations in practice. Pushing for women's equality through modernizing rhetoric may shackle the discourse so that women's historical and traditional power gets ignored. The power of women in past traditional realms is rendered invisible. By rejecting this binary, one can embrace both 'modern' forms of emancipation as well as the 'traditional,' 'cultural,' or 'religious.' It is also a way to reject the class politics that implicitly denigrates rural women or women in poverty in an attempt to privilege the image of the modern, educated woman.

The binary of modernization can be reimagined in a particularly interesting way when culture and tradition are not seen as stable. Though noting that impediments to change can exist in culture and tradition, an Egyptian representative in 2001 stated the following to the CEDAW Committee:

In this context, . . the Government, through the National Council for Women and in collaboration with the Egyptian Intelligentsia, both men and women would seek to use indigenous formulations, which were deeply rooted in Egyptian and Islamic culture and which asserted the equality between women and men ... [They] would participate in campaigns to raise awareness and ensure proper interpretations, clarify misinterpretations of religious concepts and demonstrate that the principles of sharia provide for the full equality of women with men, and respect for women's human dignity. ${ }^{176}$

175 See Sherine Hafez, The Terms of Empowerment: Islamic women activists in Egypt, 24 CAIRO PAPERS Soc. SCI., at 18-19, 100-101 (2003), for an interesting account of a woman who fills this role as an Islamic preacher in Cairo. The author notes that unlike in the more notorious example of feminist readings of Islamic by some women activists, it is not empowerment in the abstract that the women preachers seek, but empowerment that may be a means to a better Muslim ideal. 
If read as an argument made in bad faith, it could be seen as mere state rhetoric to avoid responsibility for failure to abide by international obligations. However, this could be also read as a position along the lines Sally Engle Merry describes as the productive transplantation or translation of "the human rights into local" contexts: ${ }^{177}$ an argument to see culture, religion, tradition, and customs not necessarily as the source of discrimination against women, but as different modalities in which discrimination is articulated. Thus, these instantiations can be transformed for the benefit of women as well. ${ }^{178}$

The point here, however, is precisely not to defend Islamic law in the abstract, and so it is beyond the scope of this paper to go into detail outlining the various defenses and reinterpretations within those debates. Suffice to say, there are defenses of reformist projects against more conservative ones, such as defenses of the concept of "[gender] complementarity," which results in formal differences in inheritance and within the institution of marriage. For some, under the heading of complementarity, one must read Islamic marriage regulation contextually not only in terms of men's privileges in marriage, but also in terms of how those privileges are supposedly offset by obligations such as maintenance for their wives. Much has been said and written in defense of the forms equity can take if understood as equal power between men and women in the family regardless of formal equality. ${ }^{179}$ There are also myriad reform projects that are more radical, which base interpretations on the spirit of the Qur'an as opposed to strict textual readings so that equality, not equity, is interpreted as a necessary legal reform within an Islamic framework. ${ }^{180}$ On the opposite end of the spectrum, there is much to be said in favor of a conscious deconstruction and destruction of the family as the natural unit of society, and the promotion of equality not based on a familial unit but purely in terms of individuals without inherent relational attributes. ${ }^{181}$ However, here it should only be noted that there remains room for debate about the best way to construct society around gender relations, gender roles within the family, as well as ways to think about empowering women, and

Fifth Sessions, supra note 174, at 318.

177 See Merry, Human Rights and Gender Violence, supra note 166.

178 See Sally Engle Merry, Transnational Human Rights and Local Activism: Mapping the Middle, 108 Am. AntHropologist 38 (2006).

179 See, e.g., Mashhour, supra note 121. See also Ziba Mir-Hosseini, Muslim Women's Quest for Equality: Between Islamic Law and Feminism, 23 Critical Inquiry 629 (2006).

180 See, e.g., Niaz A. Shah, Women, the Koran and International Human Rights Law: The Experience of PAKISTAN (2006).

181 See, e.g., Lee Edelman, No Future: Queer Theory and the Death Drive (2004). 
ways to reach non-discrimination. And it is a productive debate. The internal divisions and openness to international dialogue are important for the empowerment of women in countries where observance of Islamic law is foundational in the legal and social system. That is the broader context of conversations and the broader field of political questions in which the otherwise legalistic debate about "Islamic reservations" needs to be resituated.

\section{Economies of Choice}

As seen in the previous section, the arguments in favor of maintaining the institution of polygamy - when states do not have fully functioning welfare systems, or unless women indeed have equal access to the workforce, a sexual partner, and their own income - are not entertained, which means that in practice the prohibition of polygamy may in fact make some women worse off unless other background institutions are transformed or reformed. It seems that women's agency is considered negated by the background conditions. In fairness, the Committee does not take a singular view of the reforms necessary in a state by only targeting traditional practices and institutions, but also focusing on the economic access women have to the market. However, the reworking of the economic and social infrastructure simply takes more time than the abolition of laws, as if this sort of economic reworking through "access to the market" alone could fix the problem of women's oppression. Meanwhile, women's free choice seems to act as a shield from human rights scrutiny of unequal outcomes in more "modern" state contexts.

This is interesting when put in the larger context of the CEDAW Committee's record of discussing the economic dimensions for women in social institutions. Similar or corresponding practices in Europe do not receive the same level of scrutiny. It is considered beyond the scope of the Committee's mandate to intervene in the private sphere of male infidelity in marriage, or even divorce rates or the practice of multiple (sequential) marriages - all of which go against the idea of marriage as a monogamous stable institution and can have disastrous economic and emotional effects on women.

The public/private distinction functions here to create the appearance of free will in marriage as long as it looks like a union between two people and there are no gendered legal impediments to enter or exit the marriage. When the Committee questions France about the high incidence of female-headed, single-parent homes and the high incidence of divorce, they are satisfied with the State representative's answer that the situation is the result of women having a choice, since women are overwhelmingly the ones initiating 
divorce procedures. ${ }^{182}$ Despite the economic difference in male and female pay ${ }^{183}$ and the higher incidence of women in part time-work, ${ }^{184}$ the Committee allows for France's statement that the creation and dissolution of marriage is voluntary in France and that this is what women ostensibly want. Members do not ask if economic factors influence or impact these choices or if women are fully satisfied with the institution of marriage as it functions in France. ${ }^{185}$ The Committee accepts the argument of the state that it is not in a position to engineer equality around these free choices of marriage. ${ }^{186}$ The institution of marriage in France is not held to the same level of scrutiny as the institution of marriage in Iraq because women's agency is treated differently in the two situations. ${ }^{187}$ When marriage and childbearing are concerned, there is a presumption against Iraqi women's free ability to enter into a polygamous marriage. And the state is indeed asked to decide, even on the basis of a lack of knowledge, on what the French representative called defensively the kind of "private lives that women [wish] to have." Correspondingly, the biggest financial disaster that can befall a woman is having a child. Yet when women enter into this relationship, they are not considered clouded by religious or cultural ideology. The relevant difference for the CEDAW Committee between the two situations is unspoken and seemingly obvious.

To some degree the debate over women's rights has itself been constrained in such a way that this is the only way in which Committee members are able to contribute to women's empowerment. As Anne Orford has noted, it is not considered acceptable for the feminist contribution to international law to question larger structural issues, such as the international policy of economic liberalization. ${ }^{188}$ Women engaging with law are implicitly supposed to do so on or through the topic of gender, or from a gender-oriented perspective, which means very often questioning formal equality. The Committee members may have these criticisms working in the background, but they cannot be articulated given the

182 Comm. on the Elimination of Discrimination Against Women, Rep. on its Twelfth Session, supra note 129 , at 60,1354 .

183 Id. $\uparrow 345$.

184 Id. $\mid 349$.

185 Id. ๆ 355.

186 Id. ๆ 354.

187 "An uncritical acceptance of choice renders opaque the constraints that limit viable options for women in challenging social and economic situations." Angela Campbell, Sister Wives, Surrogates and Sex Workers 24 (2013).

188 Anne Orford, Feminism, Imperialism and the Mission of International Law, 71 NoRdic J. INT'L L. 275, 281 (2002). 
constraints of mandate and the subtle yet powerful norms of professional propriety. It goes without saying that rules of family law are deeply embedded within economic systems. Nordic countries, for example, are able to create rules that favor women in a particular way in part because of the tax structure. ${ }^{189}$ When there is an economic downturn, family benefits have been instrumental for women's empowerment. ${ }^{190}$ Although the welfare system in Nordic and other European countries comes under increasing pressure, these countries made an equally increasing instrumentalization of gender achievements in the name of economic competitiveness. The World Economic Forum's 2014 report on the Gender Gap, which ranks all countries based on gender equality, claims that "[b]ecause women account for one-half of a country's potential talent base, a nation's competitiveness in the long term depends significantly on whether and how it educates and utilizes its women." ${ }^{191}$ While women's formal equality has become both a means to and an argument for a particular kind of market economy, the economic particularities of how to achieve substantive equality become a second-tier consideration. Eliminating legal barriers to women's access to the market because it increases competitiveness is a fair economic argument to make, while commenting on the necessary tax structure to create women-friendly social programs would appear overly intrusive.

For a country like Egypt, the tremendous gap between rich and poor is paired with large overall poverty levels. The more the country "develops," liberalizing its economy according to international mandates and growing the GDP, the larger the gap becomes. ${ }^{192}$ With a shrinking middle class, it begs the question of how a country like Egypt could

189 See, e.g., Anne-Birte Ravn, Economic Citizenship: Debates on Gender and Tax Legislation in Denmark, 1903-1983, Freia (Feminist Research Center in Aalborg) Paper No. 51 (Dec. 2004), http://vbn.aau.dk/ files/14135482/51.pdf [perma.cc/AQ3J-9TXE]. A critical discussion of economic policies of the Welfare State as a means to implement feminist agendas can be found in Anette Borchorst \& Birte Siim, Women-Friendly Policies and State Feminism: Theorizing Scandinavian Gender Equality, 9 Feminist THeory 207 (2008). On models of gender equality related to Welfare State policies, with particular reference to the United States and Scandinavia, see Nancy Fraser, Justice Interruptus: Critical Reflections on the Post-Socialist Condition 41 (1997).

190 Comm. on the Elimination of Discrimination Against Women, Rep. On Its Twenty-Fourth and TwentyFifth Sessions, supra note 174, at 30, ๆ 284.

191 The Global Gender Gap Report 2014, World ECONOMIC ForUm, http://reports.weforum.org/globalgender-gap-report-2014 [perma.cc/4QHM-KUAP].

192 As with the general discussion on the correlation between economic liberalization and poverty in general, the issue with regard to Egypt is a debate. For a harsh indictment of liberalization, as implemented by the Mubarak regime in Egypt, see, e.g., Ray C. Bush, Politics, Power and Poverty: Twenty Years of Agricultural Reform and Market Liberalisation in Egypt, 28 THIRD WoRLD Q. 1599 (2007). 
create the economic conditions requisite to implement the kind of equality between men and women conceived of and assumed by the Committee when it examines countries that are not otherwise systematically asked about their "traditional" practices concerning women. If the Committee does not explicitly speak on which kind of economic system is required for gender equality, but eliminates traditional social and economic safety nets as de jure discriminatory, some Third World countries may be caught in a catch-22, and we risk worsening the overall situation of women in these countries. ${ }^{193}$ When assessing how best to improve women's economic position, the Committee cannot focus exclusively on women's access to the market but needs to focus equally on what kind of market women are gaining access to. ${ }^{194}$

If the reservations to CEDAW were read as compatible with the object and purpose of the treaty - which is understood to be non-discrimination against women in power relations and possibilities for women to contribute to the determination of their own fatethen the burden would be on the states to put forward interpretations and legal rules that favor women's empowerment. Opposing one particular form of "universal" gender justice does not lead necessarily to relativism and does not mean simply that "anything goes" behind the bad-faith curtain of sovereign rights. It may merely mean that a more embedded discussion needs to take place, which may be able to pay closer attention to the ways in which the public/private distinction works to create a higher level of scrutiny on Islamic law. It may also mean that women in context are dissatisfied with the results of equal treatment or formal equality as a baseline without societal support for women's specific situation and social positions, especially in regards to the family.

The Committee is in a difficult position, to be sure. Although one may always be sympathetic to the predicament of using diplomacy and negotiation, when the arguments needed to achieve their vision of equality could destroy their own legitimacy in the eyes of some parties, there are still significant consequences to the path chosen. The result of

193 One can mention here the notorious framing of gender inequality by the experts of the U.N. SubCommission on Human Rights and the Protection of Minorities in terms of the unequal burden put on women to suffer the consequences of international economic and financial pressure put on developing countries. See J. Oloka-Onyango \& Deepika Udagama (Special Rapporteurs), Globalization and its impact on the full enjoyment of human rights, Rep. of the Sub-comm'n on the Promotion \& Protection of Hum. Rts., U.N. Doc. E/CN.4/ Sub.2/2000/13 (June 15, 2000).

194 There is evidence that the wage gap between women and men is increased in economic sectors in which "overwork" or working more than 50 hours a week is the cultural norm. See Youngjoo Cha \& Kim A. Weeden, Overwork and the Slow Convergence in the Gender Gap in Wages, 79 Aм. Soc. Rev. 457 (2014). Under certain conditions, competitive market economies may in fact disadvantage women. 
this diplomatic positioning is that if the Committee pushes contentious religious doctrine into the private sphere, making it inscrutable to international public debate, there will be one fewer venue for feminists who put forward feminist readings of religion locally. When relegated to the local private sphere, women's individual relationship to the religious framing of equality and gender relations becomes either a matter of individual choice or a matter of purely theological debate to be had exclusively inside the religious institutionthat is, precisely within institutions, such as the family, the church, mosque, synagogue or others, where women are not necessarily equally represented or considered. It may not then be possible to negotiate which rules can be reread to favor women, as opposed to norms of public discourse in which there are at least governance norms calling for transparent and public discourse on the issue as well as for women to have some say in public debates.

\section{CONCLUSIONS}

By looking back at the debates that have surrounded the Shari'a reservations over the last few decades, I have proposed not so much an argument as a perspective shift. The broad-stroke arguments that painted Shari'a reservations in opposition to international human rights, instead of being constitutive of human rights, have drawn a bright line between Islamic law and human rights law. By starting from the presumption that Shari'a reservations were made in good faith and that Shari'a and women's rights are not a priori incompatible, a different discussion can be had regarding women's rights in Muslimmajority states.

There is tremendous gender oppression in Muslim-majority states. However, there is gender oppression everywhere. The uneven focus of women's rights monitoring on Islamic countries' de jure differential treatment between men and women works to mask persistent gender oppression in developed Western nations and diverts attention from substantive discrimination against women living under Shari'a. This is not to argue that Shari'a is necessarily emancipatory, nor is it any more authentically local than a secular construction, nor should it necessarily be privileged. However, the obsessive focus on reservations to human rights treaties in general, and to CEDAW in particular, has eclipsed the actual power of the treaty and the Committee's potential to work more effectively for the empowerment of women given the consensual structure of international law between states. As noted by two scholars in the field of religious studies, a different route could have been taken, or could still be taken: "Before considering possible responses by CEDAW to overly broad reservations based upon Shari'a, one should also consider the prospects for internally 
generated Islamic reform, or reforms responsive to external legal influences." ${ }^{195}$ At this moment when the International Law Commission has weighed in on the debate over Islamic reservations, there are several paths open to state parties and to the CEDAW Committee. The CEDAW Committee should welcome dialogue and step back from pushing states into formulating harder, more specific reservations.

What I have suggested is that the reading of Islamic reservations as inherently injurious to gender equality should invite scrutiny of CEDAW's own interpretation of equality. When considered in the context of the reifying treatment of Shari'a and the disproportionate attention paid to Muslim-majority countries' reservations, the interpretation of equality appears not only rigid and abstract, but also counterproductive for these reasons. As women's rights become synonymous with liberal feminism, they are pushing out other strands and traditions that would arguably offer other ways of debating what those reservations are and do. Therefore, it is not merely a religious debate at stake, but also the way we envision the center relating to the periphery-whether it is geographical, cultural, political, or methodological. Ignoring the various ways in which the public/ private binary can structure gender has helped to ensnare the international community into viewing "Islamic reservations" to CEDAW as the source of discrimination against women in Muslim-majority countries. Although this binary has been central in the development of feminist theory for the understanding of how gender is constituted, its invisible persistence as the basis of some feminist interventions continues thus to contaminate even in the field of women's rights. One should start from the basic given that discrimination against women persists in all countries, with or without reservations. By accepting the reservations of Muslim-majority countries, feminists do not ipso facto give up the emancipatory project. Indeed, employing even more consciously and diverse feminist methodologies could strengthen the project.

As it stands, states are placed in the position where they must choose between Islamic law and international law, thus perpetuating at all levels the type of dualistic logic that feminists have combated as the overall mental framing of oppression. ${ }^{196}$ This is an untenable choice for states, and a bad bet by internationalists, if they expect Muslim-majority countries to give up Islamic law as a source of law. By committing to the form of international law, giving up the project to constrain states beyond their intended commitments, and

195 Michele Brandt \& Jeffrey L. Kaplan, The Tension Between Women's Rights and Religious Rights: Reservations to CEDAW by Egypt, Bangladesh and Tunisia, 12 J.L. \& ReLigion 105, 136 (1995).

196 See, e.g., Valerie Plumwood, The Politics of Reason: Towards a Feminist Logic, 71 Australasian J. PHIL. 436 (1993). 
still holding states to their written commitment to non-discrimination of both women and Islamic law, we cannot only hope for a richer and more diverse human rights discourse, but also leave space that will privilege readings of Islamic law that emphasize women's empowerment. By allowing Islamic law into human rights, "we" risk "contamination" in the sense of perhaps giving up some preconceived notions of the particular form equality must take. ${ }^{197}$ But this kind of contamination goes both ways. ${ }^{198}$ So too does Islamic law risk giving up rigid interpretations that are determined in the debate to be less favorable to women's comparative contextual, relational, material, and spiritual empowerment. This process only takes place through a dialogical relationship. The risk of losing what we hold most dear through dialogue, the risk of being seduced by the Other into a different way of thinking, necessarily transforms us for good or bad, but it is a risk worth taking.

197 I am indebted to Brenda Cossman for influencing the structure of my methodological argument. See Cossman, Turning the Gaze Back, supra note 97, at 525.

198 Gunther Frankenberg, Stranger Than Paradise: Identity \& Politics in Comparative Law, 1997 UTAH L. REV. 259, 266 (1997) (contrasting, within the realm of comparative law, the "mainstreamer" to the "tragic comparativist," the latter being aware through the comparative exercise of the fragility and imperfections of her home legal system). 